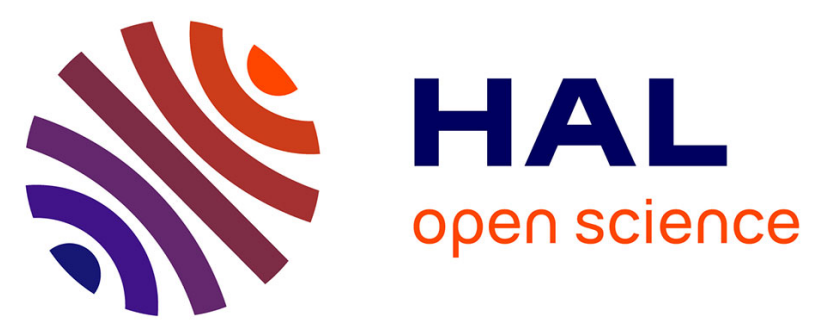

\title{
Role of the Early Miocene Jinhe-Qinghe Thrust Belt in the building of the Southeastern Tibetan Plateau topography
}

Chengyu Zhu, Guocan Wang, Philippe Hervé Leloup, Kai Cao, Gweltaz Mahéo, Yue Chen, Pan Zhang, Tianyi Shen, Guiling Wu, Paul Sotiriou, et al.

\section{To cite this version:}

Chengyu Zhu, Guocan Wang, Philippe Hervé Leloup, Kai Cao, Gweltaz Mahéo, et al.. Role of the Early Miocene Jinhe-Qinghe Thrust Belt in the building of the Southeastern Tibetan Plateau topography. Tectonophysics, 2021, 811, 10.1016/j.tecto.2021.228871 . hal-03371256

\section{HAL Id: hal-03371256 https://univ-lyon1.hal.science/hal-03371256}

Submitted on 13 Oct 2021

HAL is a multi-disciplinary open access archive for the deposit and dissemination of scientific research documents, whether they are published or not. The documents may come from teaching and research institutions in France or abroad, or from public or private research centers.
L'archive ouverte pluridisciplinaire HAL, est destinée au dépôt et à la diffusion de documents scientifiques de niveau recherche, publiés ou non, émanant des établissements d'enseignement et de recherche français ou étrangers, des laboratoires publics ou privés. 


\section{Role of the Early Miocene Jinhe-Qinghe Thrust Belt in the building of the Southeastern Tibetan Plateau topography}

\section{Chengyu Zhu', Guocan Wang,2, Philippe Hervé Leloup ${ }^{3}$, Kai Cao ${ }^{1,2}$, Gweltaz Mahéo ${ }^{3}$,} Yue Chen ${ }^{1}$, Pan Zhang ${ }^{1}$, Tianyi Shen ${ }^{1}$, Guiling Wu ${ }^{1}$, Paul Sotiriou ${ }^{4}$, Bo Wu ${ }^{1}$

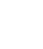

1 Center for Global Tectonics, School of Earth Sciences, China University of Geosciences, Wuhan, China.

2 State Key Laboratory of Geological Processes and Mineral Resources, China University of Geosciences, Wuhan, China.

3 Laboratoire de Géologie de Lyon: Terre, Planètes et Environnement, Université Claude Bernard, Villeurbanne, France.

4 School of the Environment, University of Windsor, Windsor, ON N9B 3P4, Canada.

\section{Corresponding author: Guocan Wang (wgcan@cug.edu.cn)}

\section{Abstract}

8 Understanding the role of southeastern Tibet thrust faults in the development of the plateau topography is key to our assessment of the geodynamic processes shaping the continental topography. Detailed structure analysis along the $\sim 400 \mathrm{~km}$ long Jinhe-Qinghe thrust belt (JQTB) indicates post late Eocene thrust motion with a minor left-lateral component, inducing $2 \sim 0.6$ to $3.6 \mathrm{~km}$ of apparent vertical offset across the fault. The exhumation history of the 3 Baishagou granite, based on the thermal modeling (QTQT) of new apatite (U-Th)/He and 4 fission-track ages, suggests an accelerated exhumation rate $(\sim 0.42 \mathrm{~km} / \mathrm{Myr})$ between 20 and 15 5 Ma, corresponding to $\sim 1.7-2.4 \mathrm{~km}$ of exhumation. We interpret that fast exhumation as due to 6 the activation of the Nibi thrust, a northern branch of the JQTB resulting in the creation of 7 significant relief across the JQTB in the Early Miocene. When compared with previous studies 8 it appears that Cenozoic exhumation and relief creation in southeastern Tibet cannot be 9 explained by a single mechanism. Rather, at least three stages of relief creation should be 0 invoked. The first phase is an Eocene NE-SW compression partly coeval with Eocene 1 sedimentation. During the Late Oligocene to Early Miocene, coevally with Indochina extrusion, 2 the second thrusting phase occurred along the Yulong and Longmenshan thrust belts, and then 33 migrated to the JQTB at 20-15 Ma. A third phase involved the activation of the Xianshuihe 
34 fault and the re-activation of the Longmenshan thrust belt and the Muli thrust. Uplift in the 35 hanging wall of thrust belts appears to explain most of the present-day relief in the southeastern 36 Tibetan Plateau.

37

38 Key words:

39 Southeast Tibet, low-temperature thermochronology, Jinhe-Qinghe thrust belt, Oligocene40 Miocene thrusting

41 
The Tibetan Plateau, the largest orogenic plateau on earth, results from complex crustal deformation processes in the context of ongoing collision and indentation of the Indian and Asian continents that commenced at least ca. 60-50 Ma ago (Molnar \& Tapponnier et al., 1975; Tapponnier et al., 2001; Hu et al., 2016). Many geodynamic models have been proposed to explain the growth and expansion of the southeastern Tibet plateau. For example, the block lateral extrusion model proposed rigid block escape along major boundary strike-slip faults, and as a consequence, crustal shortening and thickening widely distributed on the margins of the plateau (Tapponnier et al., 2001). Another model proposes that the crust thickened in the interior of Tibet propagates toward the southeastern margin in the Middle Miocene through a lower crustal flow generating the present-day continuous and gentle topography (Royden et al., 1997; Clark et al., 2005). Southeastern Tibet is a key area to quantify the on-going process of plateau migration and topography evolution because of the presence of upper crustal shortening structures as well as elevated low-relief topography deeply dissected by large rivers as a result of regional uplift and subsequent incision (Burchfiel et al., 1995; Tian et al., 2012; Clark et al., 2005a; Liu-Zeng et al., 2008; Yang et al., 2016).

The recent GPS velocity field (Zhang et al., 2004) confirmed that the plateau material migrates from the interior of Tibetan Plateau to the eastern and southeastern margin. Several studies targeted at the boundary strike-slip faults between different blocks (e.g., Leloup et al., 1995, 2001; Replumaz et al., 2001; Xu and Kamp, 2000; Zhang et al., 2017; Wang et al., 2017). Many other studies have been published on the Longmenshan (LMS) thrust belt. Only a few scattered thermochronology data have been reported from the Yalong margin in the southwest prolongation of the LMS (Figure 1), where thrust faults have been reported (Wang et al., 2012b; $\mathrm{Wu}$ et al., 2019). Most studies suggest that these thrust faults are minor and that the main Miocene thickening process is channel flow (e.g., Clark et al., 2005). Structural evidence of the thrust faults is still lacking, and would play a vital role in thermochronology data interpretation. Understanding the geometry and kinematics of these large-scale thrust faults, as well as thrustinduced exhumation pattern, is crucial for deciphering the mechanism of extrusion and the geomorphic evolution of the Tibetan Plateau.

In this paper, we re-assess the Jinhe-Qinghe thrust belt along the Yalong margin through the utilization of detailed field structure analysis. New apatite fission track (AFT) and apatite (U$\mathrm{Th}) / \mathrm{He}(\mathrm{AHe})$ ages collected along an elevation profile in the Jurassic Baishagou granite located at the hanging wall of the Nibi thrust, a northern branch of the Jinhe-Qinghe thrust belt, allows reconstruction of its cooling and exhumation history. That history provides a time 
constraint on the activation of the Jinhe-Qinghe thrust belt. The Oligocene-Miocene structural and relief evolution of southeastern Tibet will be discussed in light of these new data.

\section{Geological setting}

The Cenozoic tectonics of southeastern Tibet is marked by several large-scale strike-slip faults including the Xianshuihe, Ailao Shan-Red River and Litang faults (Figure 1) (Allen et al., 1991; Leloup et al., 1995; Zhang et al., 2015). North of the left-lateral Xianshuihe fault, a protracted history of mountain building from the Upper Triassic to the present day, has been documented in the NE-SW trending LMS thrust belt (Burchfiel et al., 1995; Roger et al., 2004; Wang et al., 2012a; Tian et al., 2013). This thrust belt is located at the sharp topographic transition from the Tibetan Plateau to the Sichuan Basin. South of the Xianshuihe fault the topographic transition is less sharp but remains steep with the average elevation dropping from $\sim 4200 \mathrm{~m}$ to $\sim 1800 \mathrm{~m}$ over a distance of 200-250 km (Liu-Zeng et al., 2008). Few detailed studies have focused on the thrust faults in this area, however, NE-SW-trending faults (e.g., Jiulong, Muli, Yulong, Jinhe-Qinghe faults) with apparent reverse motion appear on large-scale geological maps (Figure 1) (Burchfiel et al., 1995; Wang et al., 2012a; Perrineau, 2010; Cao et al., 2019). The Muli and Jinhe-Qinghe faults have been designated as the Yalong thrust belt and interpreted as the southward continuation of the LMS thrust belt (Figure 1) (e.g., Burchfiel et al., 1995; Clark et al., 2005; Wang et al., 2012b; Cao et al., 2019). The faults merge together before branching on the left-lateral Xianshuihe fault, with a ca. $60 \mathrm{~km}$ offset. The absence of any flexural basin and the relative smoothness of the relief drop with respect to that of the LMS led to the hypothesis that the present-day topography mostly resulted from passive uplift above a lower crustal channel flow that originated below central Tibet and veers around southern Sichuan, rather than from thickening along the Yalong thrust belt (Clark et al., 2005). This uplift would have warped up a low-relief erosion surface originally formed at low elevation, and induced entrenchment of the major rivers. Low-temperature thermochronology suggests that this entrenchment started at 13-9 Ma, giving a proxy for the timing of surface uplift (Clark et al., 2005; Ouimet et al., 2010). However, other studies document that other rivers in southeastern Tibet underwent entrenchment from the Oligocene to early Miocene (30-20 Ma) (Shen et al., 2016b; Tian et al., 2014). Detailed topographic studies indicate that the mean elevation drops abruptly across the Muli thrust and JQTB (Liu-zeng et al., 2008; Wu et al., 2019). Based on field observations and geological cross-sections, Perrineau (2010) estimated that $\sim 12.5 \mathrm{~km}$ and $\geq 22.5 \mathrm{~km}$ of horizontal shortening occurred across the JQTB and Muli fault, respectively, with $\sim 3.5 \mathrm{~km}$ of hanging wall uplift in both cases. Both the Yangtze and Yalong rivers exhibit large 
bends when crossing the Yulong and Muli thrusts, respectively (Figure 1). Near the Yalong bend, Wang et al. (2012b) interpret the Jinhe-Qinghe fault as a thrust fault with a left-lateral component branching on the Xianshuihe fault. Moreover, Wang et al. (2012b) deduced from the age versus elevation relationship of ten apatite fission track ages (AFT) that an increase in the apparent cooling rate beginning at $\sim 17 \mathrm{Ma}$ was indicative of the onset of the fault. However, the AFT samples appear to have been collected on the Jinhe-Qinghe fault footwall rather than the hanging wall over a large horizontal distance of about $80 \mathrm{~km}$ (Figure 2), rendering this constraint on the timing of fault onset unconvincing.

\section{Structural observations along the Jinhe-Qinghe Thrust Belt}

As described above, the Jinhe-Qinghe fault begins to branch progressively away from the Muli fault from $28^{\circ} 40^{\prime} \mathrm{N}$ southwards (Figure 1, Figure 2). The Jinhe-Qinghe fault is split into several branches (see below), accordingly, we would like to redefine it as the Jinhe-Qinghe thrust belt (JQTB), rather than the Jinhe-Qinghe fault (Wang, et al., 2012b). The main fault stretches from north of Mianning city to the Yongsheng area, east of the Chenghai thrust fault (Figure 1, Figure 2). Detailed structural analysis from six different sites along the JQTB is presented below.

\subsection{Xilaping cross-section}

This area is located near the western end of the main Jinhe-Qinghe fault, about $20 \mathrm{~km}$ to the east of the Cheng Hai thrust. At site CD608 (Figure 2), a fault damage zone with unconsolidated fault breccias and cataclastics, separates Sinian dolomite from Devonian siltstone (Figure 3a) (Geol. map G47-11). The fault strikes NE-SW and dips 60-70 $\mathrm{NW}$, to the northwest with an apparent reverse motion (Figure 2a). The Sinian dolomite is affected by several faults (Figure 3b), with the main fault plane showing nearly downdip slickensides with crystallization steps suggesting a thrust motion with a minor left strike-slip component (Figure $2 \mathrm{a}, 3 \mathrm{~d}$ and $3 \mathrm{~h}$ ). In the damage zone, ill-deformed dolomite lenses are surrounded by schistose levels. The lenses' sigmoidal shapes are compatible with reverse motion in the fault zone (Figure $3 b, 3 f$ and $3 g$ ).

\subsection{Tanjiawan cross-section}

According to the published geological maps in the Tanjiawan area, the JQTB separates gray Devonian limestone $\left(D_{2}-D_{3}\right)$ from the siliciclastic rocks of the Eocene Hongyazi Fm. (Eh) (Figure 2) (Geol. map G47-12; Wang et al., 2012b). Further northeast and to the south of the Yanyuan, the Hongyazi Fm. is thought to be Late Eocene in age, according to mammal, plant and Ostracoda fossils (Si et al., 2000). This observation is important as it implies that the JQTB fault is younger than Late Eocene in age. The Hongyazi Fm. is composed of conglomerates 
with limestone clasts at the bottom (Figure 4c) and purple/red fine-grained sandstone and siltstone in the upper part (Geol. map G47-12). Stratifications in the Hongyazi Fm. dips to the NW (Figure 4b) and unconformably overlap a Late Jurassic coal-bearing formation (Figure 4d). The precise geometry of the JQTB is obscured because of heavy vegetation (Figure 4a-b), however, it is likely a NE-SW fault that dips steeply to the NW. A cross-section indicates an apparent vertical offset of the top of the Devonian of at least $\sim 0.6 \mathrm{~km}$ and probably of $\sim 2.1 \mathrm{~km}$. (Figure 4d).

North of the Tianjiawan basin, the geological maps show an NW-SE fault placing Sinian dolomite and Paleozoic sediments on top of the Eocene rocks of the Ninglang basin (Figure 2) (Geol. map G47-11; Gao et al., 2017). The fault is called the Lizihe-Ninglang fault (LNF) (Wang et al., 2012b), and the Eocene sediments belong to the Ninglang Fm (En), which is quite similar to the Hongyazi Fm. Wang et al. (2012b) inferred the sediments to be Oligocene to Miocene in age. However, they are intruded by a series of granitic bodies (Figure 2, 4f) (Geol. map G47-11), one of which has been dated at $33.1 \pm 0.2 \mathrm{Ma}$ (Early Oligocene) by zircon U-Pb geochronology (Figure 4f, 4g; Table S1). This age confirms that the Ninglang Fm. is no younger than Early Oligocene, and may have a similar age to the Hongyazi Fm., implying that the LNF initiated after the Late Eocene-Early Oligocene. To the south, the LNF appears to be cut by a branch of the JQTB (Figure 2) suggesting LNF could be older rather than a branch of JQTB.

\subsection{Qinghe-Dalaluo cross-section}

The middle segment of the JQTB is exposed on the road from Panzhihua to Yanyuan (section C-C', Figure 2). In this area, the thrust belt veers from NNE-SSW to E-W and comprises two branches with the southern one being the primary fault. According to the geological map, the southern fault branch is itself composed of two splays, the lower, southern one trending N90 and bringing Sinian rocks on top of Permian-Triassic rocks (Figure 5d). The apparent vertical offset of the upper Devonian strata is estimated to be at least $700 \mathrm{~m}$ but more probably on the order of ca. $3.6 \mathrm{~km}$ (Figure 5c). Our observations at site CD 461 show a large fault plane striking $\mathrm{N} 80^{\circ}$ and dipping $\sim 50^{\circ} \mathrm{NNW}$ that bears slickensides trending $\mathrm{N} 298^{\circ}$ (red planes in Figure $2 \mathrm{~b}$ ). According to the geological map, the northern branch of the JQTB strikes N60 ${ }^{\circ}$ and brings Devonian sediments on top of folded Carboniferous limestone with an apparant vertical offset of the upper Devonian strata of $\sim 1 \mathrm{~km}$ (Figure 5c and 5d). At site CD462, the bedrock is highly fractured, and a series of subparallel secondary reverse faults form an imbrication zone with roof and floor thrusts bounding a dolomite fragment and forming a duplex structure (Figure 5a). This geometry suggests a top to the east thrust motion (black planes in Figure 2b). A large 
fault plane strikes $\mathrm{N} 5^{\circ} 35^{\circ}$ and bears slickensides trending $\mathrm{N} 338^{\circ}$ with steps suggesting leftlateral (with minor thrust) motion (Figure 5b).

\subsection{Jinhe cross-section}

East of $100^{\circ} 30^{\prime} E$ the strike of the JQTB veers from NE-SW to N-S (Figure 2) (Figure 6g). The JQTB can be continuously traced for more than $100 \mathrm{~km}$ from site CD461 of the Qinghe-Dalaluo section until site 128 , near the Jinhe town, where the fault strikes $\mathrm{N} 60^{\circ} 65^{\circ} \mathrm{N}$ and places Sinian rocks (gabbros and Sinian limestones) over Upper Permian basalts (Figure 6f, 6d). The fault zone is complex with several parallel fault traces. Most faults dip steeply to the $\mathrm{W}$, but locally Devonian limestone is thrust over Triassic-Jurassic siltstone along a flatter surface (Figure 6f, g). To the west, at site CD599, a fault strikes $\mathrm{N} 30^{\circ} 45^{\circ} \mathrm{W}$ with the hanging wall comprising Sinian and Paleozoic rocks, while drag folds are found adjacent to the fault zone implying a thrusting movement (Figure 6a-c). From a cross-section (Figure 6f), the apparent vertical component of motion on the JQTB can be estimated between 1.4 and $2.8 \mathrm{~km}$ according to the offset of the base of the Triassic (Figure 6f).

East of the JQTB, Late Triassic siltstone with interbedded coal beds and Jurassic siltstone are strongly folded by a series of anticlines and synclines with axes subparallel to steeply-dipping $\mathrm{N}-\mathrm{S}$ reverse faults, the most prominent one being the Hanjiawanzi fault that brings Triassic rocks on top of Jurassic rocks (Figure 6f). Further east, Mesozoic sediments are separated from the Aqi batholith by a west-dipping fault with an apparent normal throw that we term the Aqi fault (Figure 6f) (Figure 2). Both the Hanjiawanzi and Aqi faults extend further to the south (Figure 2).

\subsection{Mianning-Yalong cross-section}

North of the Jinhe cross-section the JQTB can be followed to the NNW to the Lizhuang area, bringing Sinian rocks (Zbd) above Mesozoic sediments (Figure 2) (Geol. map G47-06). Near Lizhuang, the JQTB and the Yalong fault branch together before turning to the NNE and becoming progressively more linear closer to the Muli thrust (Figure.2). The kinematics of the Yalong fault is thrust with a sinistral component which has been interpreted as a branch of the JQTB (Wang et al., 2012b).

Sites CD733 and CD734 show evidences for $\sim$ N-S-trending faulting. At site CD733, fault gouge in the granite exhibits fault planes striking $\mathrm{N} 355^{\circ} 22^{\circ} \mathrm{N}$ with slickensides striking $\mathrm{N} 265^{\circ}$, indicative of dominating thrusting motion (Figure 2d, 7a-b). At site CD734, there is a tectonic boundary between the yellow sandy slate and the black carbonaceous slate (Figure 7c). The contact plane show undulations and strikes $\sim \mathrm{N} 30^{\circ}$ and dips $25-35^{\circ} \mathrm{W}$ (Figure $2 \mathrm{~d}$ ). S-C fabrics 
and asymmetric lens near the contact surface suggest left-lateral thrust motion (Figure 7d). These two observation sites occur along the Nibi fault mapped $\sim 8 \mathrm{~km}$ east of the Yalong fault (figure 2) (Geol. map H47-36). To the south, the Nibi fault possibly extends to the Lizhuang area (Wang et al., 2012b), as a branch of the JQTB. It is unlikely that the Nibi fault connects with the Aqi fault, which is a normal fault in the south parallel to the J QTB (Geol. map G4706), while to the north its trace is obscured by Quaternary sediments.

At site CD760, west of the left-lateral Anninghe fault, a fault striking N50 ${ }^{\circ}$ separates Sinian granites and Permian basalts (Figure 2) (Geol. map H48-31). Although the contact relationship is unclear due to heavy vegetation, the granites and the Permian metamorphic basalts are deformed and cataclastic near the contact (Figure 8b). Fault planes found in the basalt are nearly vertical, strike $\sim \mathrm{N} 20^{\circ}$ and show two groups of slickensides: one trending $\mathrm{N} 15^{\circ}$ and the other one trending $\mathrm{N} 210^{\circ}$. The former one shows left-lateral with minor thrust motion, while the latter one shows left-lateral motion with a minor normal component (Figure 2e). In the field, the latter crosscuts the former.

\section{Thermochronological constraints of the JQTB}

4.1 Sampling strategy and methods

Low-temperature thermochronology (e.g., fission track and (U-Th)/He) is widely used in mountain building and landscape evolution to reconstruct the upper crustal cooling/exhumation history (e.g., Shen et al., 2016a; Schildgen \& Van der Beek., 2019). Complex structures and strong topography affect isotherms in the upper crust which may significantly influence fission track ages (Braun, 2002). To constrain the exhumation rate, it is thus better to sample along vertical transects. We sampled an altitudinal transect (Baishagou transect) in the hanging wall of the Yalong thrust over a relief of $\sim 1000 \mathrm{~m}$ and culminating at $2443 \mathrm{~m}$ (Figure 2, 7e). The horizontal distance of the Baishagou transect is $\sim 1.3 \mathrm{~km}$ to reduce the topography effect as much as possible. The nine samples were collected in an undeformed granite, the Jurassic Baishagou granite (Figure 2) (Wang et al., 2014). They yielded nine AFT ages (Table 1) and four AHe ages (Table 2). Neither deformation nor faults were detected in-between the samples. Apatite fission track samples were dated by the LA-ICP-MS method (Gleadow et al., 2015). Apatite grains were set in a regular array in epoxy resin and polished to expose a flat surface for etching. Following this, the AFT grains were etched in $5 \mathrm{~N} \mathrm{HNO}_{3}$ at $21^{\circ} \mathrm{C}$ for $20 \mathrm{~s}$ to reveal the spontaneous tracks. Sample preparation and spontaneous fission-track counting were performed at the State Key Laboratory of Geological Processes and Mineral Resources, China University of Geosciences, Wuhan, using the Autoscan system. In order to reduce the error due 
to the low spontaneous track density, we tried to choose the largest grains and count the track density in the area as wide as possible. The U content was measured by an Agilent 7700e LAICP-MS at the State Key Laboratory of Geological Processes and Mineral Resources. The parameters for laser ablation was set as $32-\mu \mathrm{m}$ spot size, $4.5 \mathrm{~J} / \mathrm{cm} 2$ and $6 \mathrm{HZ}$ repetition rate. NIST 612 glass and $43 \mathrm{Ca}$ of apatite were used as an internal standard to correct the U concentrations of apatite aliquots.

AHe analyses were conducted at the University of Arizona, USA. Four grains without visible inclusions and fracture per sample have been carefully selected. The radius and mass of each grain was measured before dating. The grains were loaded into $\mathrm{Nb}$ tubes and heated with a laser before cryogenic purification. Helium contents were measured using quadrupole mass spectrometry. Subsequently, aliquots were dissolved in dilute HNO3 and the U, Th, and Sm contents have been obtained through ICP-MS (Ehlers \& Farley, 2003). Measured ages have been corrected by applying the $\alpha$-ejection correction (Farley, 2002). Durango apatite grains $(31.4 \pm 0.5 \mathrm{Ma})$ were analyzed together with our unknow age aliquots to check the reliability and stability of the measurement.

\subsection{Pseudo-elevation and age profile}

The AFT ages from the Baishagou transect range between 26.9 Ma and 16.7 Ma and show a strong relationship with altitude with all samples below $2198 \mathrm{~m}$ being younger than $\sim 18.5 \mathrm{Ma}$ (Figure 9a). All ages were calculated from high-quality grains that have a homogeneous track distribution, lack inclusions, and involved counting as large an area as possible. The $\chi^{2}$ test of all samples is $>5 \%$ with low age dispersion, indicating a single age population. The three $\mathrm{AHe}$ ages gave similar ages at $\sim 15 \mathrm{Ma}$. To ensure a better interpretation of the exhumation history, an AFT age vs elevation (Figure 9a) and a composite AFT and AHe age vs pseudo-elevation (Figure 9b) diagram were plotted. For the pseudo-elevation diagram, the AHe ages were plotted against true elevation, while the AFT ages elevations were increased by a constant value calculated from the closure temperature difference between the AFT and AHe systems (Reiners and Brandon, 2006). Assuming a geothermal gradient of $30^{\circ} \mathrm{C} / \mathrm{km}$, a closure temperature of 65 ${ }^{\circ} \mathrm{C}$ and $110^{\circ} \mathrm{C}$ for AHe and AFT thermochronometric systems respectively (Farley, 2002; Wagner and van den Haute, 1992) suggests an increase in elevation of $1500 \mathrm{~m}$.

Sample CD753 yielded three AHe grain ages (Table 2), however, two of them are older than the corresponding AFT age (16.9 $\pm 1.4 \mathrm{Ma})$, probably caused by U/Th zoning (Farley et al., 2011), radiation damage (Shuster et al., 2006) or inclusions (Vermeesch et al., 2007), and have 
been discarded. Furthermore, we prefer to not use the third single crystal age whose reproducibility cannot be tested and thus not consider sample CD753 AHe age.

The obtained plot can be interpreted in two different ways (Fig 9b).

(1) A single event model corresponding to one constant Oligocene-Miocene exhumation. The mean exhumation rate calculated by the single least-squares regression slope is $\sim 0.15 \mathrm{~km} / \mathrm{Myr}$ with a relatively low correlation coefficient $\left(\mathrm{R}^{2}=0.69\right)$, and two AFT and two AHe samples outside of the $95 \%$ confidence interval (grey array on Figure 9b).

(2) A two episodes exhumation history, with a break in slope at $2200 \mathrm{~m}$ and $\sim 19 \mathrm{Ma}$ (blue arrays, Figure 9b). The linear regression of the upper part of the profile corresponds to a very slow exhumation rate of $\sim 0.03 \mathrm{~km} / \mathrm{Myr}\left(\mathrm{R}^{2}=0.99\right)$, while the lower part shows a relatively rapid exhumation of $\sim 0.31 \mathrm{~km} / \mathrm{Myr}$ between $\sim 19$ and $14 \mathrm{Ma}\left(\mathrm{R}^{2}=0.90\right)$ that would correspond to at least $1700 \mathrm{~m}$ of exhumation.

Given the difference in age between the AFT and AHe for a given sample, this can yield estimates of the cooling rate. Assuming that the closure temperature of AFT and AHe system is $65^{\circ} \mathrm{C}$ and $110{ }^{\circ} \mathrm{C}$ respectively (Farley, 2002; Wagner and van den Haute, 1992), the rates would be $\sim 4{ }^{\circ} \mathrm{C} / \mathrm{Ma}$ between $\sim 27$ and $15 \mathrm{Ma}$ for $\mathrm{CD} 746, \sim 7^{\circ} \mathrm{C} / \mathrm{Ma}$ between $\sim 22$ and $15 \mathrm{Ma}$ for CD747, and $\sim 11^{\circ} \mathrm{C} / \mathrm{Ma}$ between $\sim 19$ and $14 \mathrm{Ma}$ for CD749. This suggests that the cooling rate significantly increased after $19 \mathrm{Ma}$. This strongly suggests that the increase in the cooling rate is correlated with the increase in the exhumation rate outlined in the two stages model (Figure $9 \mathrm{~b}$ ) and thus that it reveals an increase in the exhumation rate at $\sim 19 \mathrm{Ma}$. Furthermore, the two highest samples (CD746 and CD747, Table 1) show shorter track lengths than the other samples (Table 1) indicating that they stayed in the AFT PAZ during the slow cooling phase until 22 Ma prior to cool rapidly together with the other samples.

\subsection{Thermal Modeling}

To better constrain the cooling and exhumation history of the Baishagou granite, we performed QTQt modeling (Gallagher, 2012) based on the nine AFT ages and three AHe ages. In this model, prior constraints are as follows: (a) the present-day surface temperature is $10 \pm 10^{\circ} \mathrm{C}$; (b) the default geothermal gradient is $\sim 30 \pm 30^{\circ} \mathrm{C} / \mathrm{km}$. (c)The temperature offset was permitted to vary over time because of the unstable paleo-geothermal gradient. (d)We did not dispose of any precise and reliable constraints on the temperature-time history of the Baishagou granite and the QTQt models were performed without any external constraint, to avoid overinterpretation of the modeling result (Vermeesch \& Tian, 2014). (e) 100,000 burn-in and post-burn-in iterations were performed for the modeling to get a stable result. The modeling 
results are shown in Figure 10, including the maximum likelihood model and the expected model derived from the QTQt inverse modeling.

The maximum likelihood model corresponds to the model with the lowest misfit with the data (Gallagher, 2012). It reproduces well the AFT and AHe ages and the track length data (Figure $10 \mathrm{a}, \mathrm{b})$. This model presents a three-stage cooling history. First $\sim 20 \mathrm{Ma}$ of slow cooling from $\sim 140$ to $130{ }^{\circ} \mathrm{C}$ at a rate of $\sim 0.5{ }^{\circ} \mathrm{C} / \mathrm{Myr}$, second rapid cooling between 20 and $15 \mathrm{Ma}$ at a rate of $10{ }^{\circ} \mathrm{C} / \mathrm{Myr}$, and third slow cooling from $\sim 60-40^{\circ} \mathrm{C}$ at a rate of $\sim 2{ }^{\circ} \mathrm{C} / \mathrm{Myr}$ (Figure 10a). The timing of initiation of the fast cooling phase at $\sim 20 \mathrm{Ma}$ is similar to the timing of the break-in slope in the pseudo-elevation age profile (Figure 9b). Subsequently, the rocks underwent a faster cooling that we interpreted to have resulted from the rapid exhumation of the rocks. Taking the geothermal gradient calculated from the QTQt model $\left(30^{\circ} \mathrm{C} / \mathrm{km}\right.$ for the first episode and $26^{\circ} \mathrm{C} / \mathrm{km}$ for the others), the exhumation rate between 20 and $15 \mathrm{Ma}$ is $0.415 \pm 0.075$ $\mathrm{km} / \mathrm{Myr}$ corresponding to $\sim 1.7-2.4 \mathrm{~km}$ of total exhumation. After $\sim 15 \mathrm{Ma}$, a period of slow cooling corresponds to less than $\sim 1 \mathrm{~km}$ of exhumation.

The expected model is a weighted mean model that yields a range of possible cooling histories at a $95 \%$ range for each parameter and is expected to show smoother cooling histories than the maximum likelihood model (Gallagher, 2012). As a matter of fact, the results show a more progressive transition from slow $\left(\sim 1-2{ }^{\circ} \mathrm{C} / \mathrm{Myr}\right)$ to relatively fast cooling $\left(\sim 7-8{ }^{\circ} \mathrm{C} / \mathrm{Myr}\right)$ to at about $24-20 \mathrm{Ma}$, followed by a stage of moderate cooling $\left(\sim 2-3{ }^{\circ} \mathrm{C} / \mathrm{Myr}\right)$ after $\sim 15-11 \mathrm{Ma}$ (Figure 10c). The fit between predicted and observed ages in this model is not as good as the maximum likelihood model, even though the results are within the error bars (Figure 10d).

To conclude, both models imply a relatively fast cooling period (10 to $\left.7^{\circ} \mathrm{C} / \mathrm{Myr}\right)$ between 24 20 and 15-11 Ma, which we interpret as the result of rapid exhumation.

\section{Discussion}

5.1 Exhumation mechanism(s) of the Baishagou granite Few published thermochronology studies have focused on the exhumation of the Yalong region of the JQTB (Figure 1). Wang et al. (2012b) reported a fast exhumation at $\sim 17$ Ma derived from AFT samples scattered along a $\sim 80 \mathrm{~km}$ horizontal distance in the footwall of the Yalong fault (Figure 2). Upstream along the Yalong river, Clark et al. (2005) reported 13-9 Ma rapid river incision from samples collected from the upper wall of the Muli thrust fault. Our data imply that the fast cooling of the Baishagou granite occurred between 24-20 and 15-11 Ma. It is more likely that this cooling occurred between 20 and $15 \mathrm{Ma}$ at a rate of $10^{\circ} \mathrm{C} / \mathrm{Ma}$ and corresponds to $\sim 1.7-2.4 \mathrm{~km}$ of exhumation at a rate of $\sim 0.4 \mathrm{~km} / \mathrm{Myr}$. The granite lies in the deep Yalong 
river gorges in the footwall of the Muli thrust and the hanging wall of the Yalong and Nibi faults (Figure 2). Two main processes can be proposed for exhumation: fluvial erosion or uplift in the hanging wall of a thrust fault. However, a more regional uplift mechanism cannot be ruled out. For example, some workers have linked the deep erosion of the Yalong river to lower crustal flow at depth that would have propagated from the Tibetan Plateau towards the southeast during the Late Miocene ( $\sim 13 \mathrm{Ma}$ ) (Clark \& Royden, 2000; Clark et al., 2005; Ouimet et al., 2010). As discussed above the timing of exhumation of the Baishagou granite is constrained to start $\sim 20 \mathrm{Ma}$, which is significantly older than the age proposed for the onset of exhumation linked with lower crustal channel flow in that area ( $\sim 13$ Ma, Clark \& Royden, 2000; Clark et al., 2005). This will be discussed in more detail below.

The Anninghe fault is an active left-lateral strike-slip fault that is the southern extension of the Xianshuihe fault system and is located along the Anninghe River $32 \mathrm{~km}$ east of the Baishagou granite (Figure. 2). This fault could have played a role in the exhumation of the Yalong area. However, it is a strike-slip fault with a very small vertical component that could probably not have induced the $\sim 2 \mathrm{~km}$ exhumation recorded in the Baishagou region. For example, the slickensides observed at site CD760 probably belong to a branch of the Anninghe fault and show very little vertical component (Figure 2). Furthermore, the fault is the prolongation of the Xianshuihe fault, which is considered to be younger than 9 Ma (Zhang et al, 2017), or even possibly $\sim 5 \mathrm{Ma}$ (Wang et al., 2009) at this location.

Alternatively, several faults straddle the Mianning-Yalong zone (Figure 2, Figure 7e) and could have induced the exhumation of the Baishagou granite. The Muli fault is an NW dipping thrust outcropping $12 \mathrm{~km}$ to the NW and would thus induce subsidence, not uplift, of the Baishagou granite. Alternatively, the granite lies in the hanging wall of the Yalong and Nibi thrusts (Figure 2, Figure 7e). Wang et al. (2012b) provided the AFT ages of ten samples from four locations in between the Yalong and Nibi faults (Figure 2). When plotted together with our data, their ages define roughly the same age versus altitude relationship implying a strong common exhumation between $\sim 20$ and $15 \mathrm{Ma}$ (Figure 9a). Because all these samples are in the hanging wall of the Nibi fault, it suggests that this fault is responsible for this exhumation. The upper part of the plot, however, possibly shows a $\leq 7$ Ma offset between the two data sets (Figure 9a). Such offset could result from a faster exhumation of the samples west of the Yalong fault until $20 \mathrm{Ma}$, which would be compatible with a small reverse motion on the fault at that time. After $20 \mathrm{Ma}$, both data sets show fast exhumation that we have constrained to be at $\sim 0.4 \mathrm{~km} / \mathrm{Ma}$ until $15 \mathrm{Ma}$ from the QTQt modeling of our data. Data from Wang (2012b) suggest that fast exhumation lasted until $\sim 15 \mathrm{Ma}$ and was followed by a slower exhumation phase (Figure 9a), suggesting 
that the Nibi fault ceased at that time. A $1300 \mathrm{~m}$ elevation difference is observed from the Anninghe valley bottom to the ridge in the hanging wall of the Nibi fault. We suggest that most of this difference results from the $\sim 1.7-2.4 \mathrm{~km}$ early Miocene fast exhumation in the hanging wall of the Nibi fault.

\subsection{Timing of the Jinhe-Qinghe Thrust Belt}

As described above, the JQTB runs for more than $300 \mathrm{~km}$ from the Yalong-Mianning area to the Xilapin area, bringing Sinian rocks on top of Mesozoic sediments (Figure 2). Our field observations confirm that the JQTB is a thrust with $\sim 0.6$ to $3.6 \mathrm{~km}$ of apparent vertical offset. Locally, the JQTB shows a large left-lateral component (Figure 2b - site CD462, d), but where it trends E-W it shows a right-lateral component (Figure $2 b-$ site CD461). The amount of strike-slip displacement is difficult to estimate and is most probably small. In Tanjiawan, Eocene sediments are found in the footwall of the JQTB implying that the fault is younger than $33.1 \pm 0.2 \mathrm{Ma}$ (Figure 4g).

In the Mianning-Yalong zone, the Nibi thrust was active since $20 \mathrm{Ma}$. The prolongation of the thrust to the south is not clear, but one possibility is that it is a branch of the JQTB (Figure 2). The amount of exhumation between 20 and $15 \mathrm{Ma}$ in the hanging wall of the Nibi fault constrained from the thermochronology data is $\sim 1.7-2.4 \mathrm{~km}$, which is on the same order than the $\sim 0.6$ to $3.6 \mathrm{~km}$ of apparent offset on the JQTB. This confirms that the Nibi fault is the northern prolongation of the JQTB that has been active between $\sim 20$ and $\sim 15 \mathrm{Ma}$.

\subsection{Regional tectonic implications}

\subsubsection{Compatibility with the channel flow model}

One of the processes that have been invoked for the uplift/exhumation of the southeastern Tibet margin is a flow of partially molten lower crust pushed outward from the Tibetan Plateau by body forces due to its exceptional thickness. The flow would be halted and pushed upward by the stiff Sichuan craton to create the LMS range, while it would be continuous across the Yunnan margin inducing a smoother relief. In that model, an uplift wave would progressively propagate from west to east, inducing river incision and erosion ((Clark \& Royden, 2000; Clark et al., 2005). The Yalong river incision at 13-9 Ma derived from AFT and AHe data was taken as a proxy for river incision and thus the propagation of channel flow across the Yalong margin (Clark et al., 2005; Ouimet et al., 2010).

However, a growing number of studies document erosion/exhumation timings that are not in accord with the channel flow hypothesis, i.e. a simple propagation from west to east through 
404

405

406

407

408

409

410

411

412

413

414

415

416

417

418

419

420

421

422

423

424

425

426

427

428

429

430

431

432

433

434

435

time (Figure 1). For example, surface uplift in the Daocheng took place between $\sim 22$ and 15 Ma (Figure. 1) (Tian et al., 2014), whilst other fast exhumation of the hanging wall along the Jiulong thrust fault took place at $\sim 35-30 \mathrm{Ma}$ and between 8 and $7 \mathrm{Ma}$ (Zhang et al., 2016). Near Xiangcheng, the fast exhumation and entrenching of the Shuoqu River (upper reach of the Yangtze River) lasted from 18-15 to 12 Ma (Gourbet et al., 2019). Along the Jiulong River, incision started at 13-9 Ma (Clark et al., 2005), whilst our study located further downstream of the Yalong river and $15 \mathrm{~km}$ east, documents exhumation starting at $20 \mathrm{Ma}$. Such timing is incompatible with a channel flow model for the entrenching of the Yalong river.

\subsubsection{Diachronous Cenozoic exhumation of southeastern Tibet}

In the LMS region, two main episodes of rapid exhumation phases during the Cenozoic have been documented. In the central LMS region, these two phases have been dated by lowtemperature thermochronology in the Pengguan range at 30-25 to 25-20 Ma (Wang et al., 2012a) and $\sim 11$ Ma to the present day (Godard, 2009; Wang et al., 2012a). This has been interpreted as two episodes of mountain building, the younger one is still active as shown by the Wenchuan earthquake. In the southwest LMS, the exhumation of the Baoxing granite started prior to 17$15 \mathrm{Ma}$, while the exhumation in the hanging wall of the Wulong fault started at 12-10 Ma (Cook et al., 2013) (Figure 1).

The left-lateral Xianshuihe fault separates the southern LMS from the Yalong thrust (Figure. 1). The total offset has been estimated at $\sim 60 \mathrm{~km}$ (e.g., Wang et al., 1998; Wang and Burchfiel, 2000; Yan and Lin, 2015). The timing of onset is disputed, however, Zhang et al. (2017) proposed that it initiated at 12.6 \pm 1 Ma in the NW (Wang et al., 2009) and propagated between the LMS and Yalong thrust at $\sim 9$ Ma.

Tapponnier et al. (2001) suggested that the thrusts of the Yalong margin correspond to thrusts branching on the Xianshuihe fault during the Eocene-Oligocene. Wang et al. (2012b) also suggested that the JQTB was a thrust with a large lef-lateral component branching of the Xianshuihe fault active at $\sim 17 \mathrm{Ma}$ (Middle Miocene). Our results confirm the timing proposed by Wang et al. (2012b), however, this hypothesis does not fit with the age of the Xianshuihe fault which is significantly younger in that area ( $\sim 9 \mathrm{Ma}$ ) (Zhang et al., 2017).

To the SW, the JQTB seems to cut the LNF (Figure 2). The LNF thrust is younger than Eocene sediments older than $33.15 \pm 0.21 \mathrm{Ma}$. The LNF trends NNW-SSE almost parallel to the Chenghai and Yulong thrusts. The age of the Yulong thrust has been proposed to be between 28 and $20 \mathrm{Ma}$ (Cao et al., 2019), coeval with E-W compression and left-lateral shear along the 
Ailao Shan-Red River (ASRR) shear zone (Leloup et al., 1995, 2001, 2007). An age of 28 to $20 \mathrm{Ma}$ for the LNF would be compatible with the age that we propose for the JQTB (20-15 Ma). It thus appears that a single model cannot explain all the exhumation ages now available in southeastern Tibet and that one should envisage several exhumation mechanisms taking place during a multistage history.

\subsubsection{Multistage history for the growth of relief in the southeastern Tibetan Plateau} The growing data set on the timing of exhumation, including the present study and paleoaltimetry suggest that several mechanisms contributed to the formation of the present-day topography in southeastern Tibet. Below we list several tectonic events that have contributed to the topographic growth of eastern Tibet.

Mesozoic deformation has been widely documented in the eastern Tibet (e.g., Roger et al., 2010), and Cretaceous deformation and metamorphism occurred in the south LMS (e.g., Airaghi et al, 2018) and Danba area (Wallis et al., 2003). These events have probably produced significant relief. However, it is unclear how much of that relief was preserved prior to the Early Eocene at the time of the India-Asia collision. The Jianchuan Eocene basin formed in the footwall of the Ludian-Zhonghejiang thrust that was active between 50 and $39 \mathrm{Ma}$ according to low-temperature thermochronology (Figure 1, Figure 11) (Cao et al., 2020). Such deformation implies NE-SW shortening (in present-day coordinates) (Figure 12a) and is comparable to deformation and sedimentation of the HohXil and Yushu-Nangqian basins further west in the Tibetan Plateau (Horton et al., 2002; Spurlin et al., 2005; Staisch et al., 2016). Such deformation produced crustal shortening responsible for significant relief creation. Indeed, some paleo-elevation studies indicate that parts of southeastern Tibet reached high elevation before the Oligocene: Liming basin, $2650 \pm 300 \mathrm{~m}$ at $\geq 40 \mathrm{Ma}$ (Hoke et al., 2014), the Jianchuan basin, $2.9 \pm 0.6 \mathrm{~km}$ at $\sim 36 \mathrm{Ma}$ (Wu et al., 2018), the Gonjo basin, $\geq 2100-2500 \mathrm{~m}$ at $\geq 43 \mathrm{Ma}$ (Tang et al., 2017), the Markam basin, $3 \mathrm{~km}$ at $\sim 34 \mathrm{Ma}$ (Su et al., 2018). However, studies relying on $\delta^{18} \mathrm{O}$ measurements probably overestimated the paleo-elevations (Botsyun et al., 2019). For example, in the Jianchuan basin, the Eocene ( 36 Ma) altitude could be re-evaluated to $1200 \pm 1200 \mathrm{~m}$ depending on the assumptions made for the Eocene conglomerates (Gourbet et al., 2017; Wu et al., 2018). In any case, at least 1 to $2 \mathrm{~km}$ of altitude needs to have been gained after the Eocene in western southeastern Tibet and probably much more in the rest of the area.

During the Late Eocene-Early Oligocene (35-30 Ma) only one phase of exhumation is documented in eastern Tibet, which is in the hanging wall of the Jiulong thrust (Figure 11, 
Figure 12a) (Zhang et al., 2017). That time corresponds to a major phase of ultrapotassic magmatism dated between 36.9 and 32.5 Ma. (Schärer et al., 1994; Liang et al., 2007; Chung et al., 2008; Lu et al., 2012). The products of this magmatism are found in a zone with a diameter of $\sim 200 \mathrm{~km}$ that was latter cut and offset $\sim 600 \mathrm{~km}$ by the left-lateral ASRR (Leloup et al., 2001). A phase of magmatism at 33 Ma followed by rapid cooling until $29 \mathrm{Ma}$ in the Xuelong Shan range has been interpreted as taking place after the onset of the shear zone (Leloup et al., 2001; Leloup et al., 2007). Gourbet et al. (2017) proposed that doming of the upper crust under the effect of rising magmas due to ultrapotassic magmatism (Figure 12a) would have been sufficient to provoke a major drainage reorganization. Other studies have linked the ultrapotassic magmatism to lithospheric delamination (Chung et al., 1998, 2005; Lu et al., 2012), in which case it would have induced a large regional uplift. However, such a hypothesis would require extension, rather than compression, at the time of magmatism.

In the Late Oligocene-Early Miocene (30-20 Ma) (Figure 12b), a major phase of exhumation has been documented interpreted as resulting from a first phase of thrusting along the LMS thrust belt (Figure 11) (Wang et al., 2012a), indicating NW-SE compression. Contemporaneous exhumation (28-20 Ma) of the Jianchuan basin has been interpreted to be linked to the Yulong thrust fault (Cao et al., 2019) suggesting WNW-ESE compression. The Chenghai and LNF thrust most probably activated at the same time (Wang et al., 2012b; Cao et al., 2019). This resulted in the creation or amplification of the relief in the hanging wall of the faults (Figure 12b). As both the Yulong and LMS thrust belts were active at this time, it is tempting to consider that the Muli fault located in between would have also been active. The later activity of that fault is likely based on low-temperature thermochronology (see below), however, the lack of higher temperature thermochronology data precludes any definitive answer.

During 20-15 Ma, the Nibi thrust was active and thus most probably the Jinhe-Qinghe thrust (Figure 12c), with 0.6 to $3.6 \mathrm{~km}$ of apparent vertical offset inducing 1.7 to $2.4 \mathrm{~km}$ exhumation of the hanging wall. Relief creation in the hanging wall of the Jinhe-Qinghe thrust expanded the high Tibetan relief to the southeast. Differential uplift is still visible in the $\sim 1200 \mathrm{~m}$ topographic step across the JQTB (Perrineau, 2010; Wu et al., 2019). No significant exhumation has been documented in the central LMS, however, Cook et al. (2013) report a phase of exhumation starting prior to $15 \mathrm{Ma}$ in the Baoxing granite, which is located in the hanging wall of the Erwangmiao fault in the southwestern LMS (Figure 12c). At $15 \mathrm{Ma}$, all parts of the topographic transition from Tibet to areas of lower elevation had been uplifted and the relief could have been comparable to the present-day relief. Correspondingly, the clastic sediments 
denudated from southeastern Tibetan Plateau were transported to the South China Sea by large river systems (e.g., Paleo-Red River) with peaks in the sediment flux at $\sim 19 \mathrm{Ma}$ and 17-15 Ma (Clift et al., 2006, 2014), which fits our proposed 20-15 Ma accelerated exhumation very well. The extrusion of Indochina along the ASRR ended at $~ 17$ Ma (Leloup et al., 2001) marking a major tectonic change in the area. One could expect that the Jiulong and Muli thrusts and JQTB would have been activated in that order following the propagation of the Tibetan Plateau toward the southeast, or an in-sequence thrusting from the plateau interior. This is based on the fast exhumation documented at the thrust fault hanging walls of the Jiulong, Muli and Nibi (JQTB) thrusts that show phases of rapid cooling at between $\sim 35$ and $30 \mathrm{Ma}$ and between 8 and $7 \mathrm{Ma}$ (Zhang et al., 2016), between $\sim 13$ and $5 \mathrm{Ma}$ (Clark et al., 2005) and between 20 and $15 \mathrm{Ma}$ (this study), respectively (Figure 1, Figure 12a-c). Higher temperature thermochronology system (ZHe and ZFT) focusing on the Muli thrust will possibly provide more information about the earlier exhumation phase of the Muli thrust and its mechanism.

After the end of Indochina extrusion, the left-lateral Xianhuihe fault initiated at $13 \mathrm{Ma}$ in the northwest (Wang et al., 2009) and propagated to the southeast, reaching the Gongga Shan area at $\sim 9 \mathrm{Ma}$ (Zhang et al., 2017), and further to the southeast probably at $\sim 4 \mathrm{Ma}$ (Figure 12d). The dextral Red River fault initiated along the former ASRR possibly at $\sim 12$ Ma (Leloup et al., 2001; Wang et al., 2016), or at 5 Ma (Leloup et al., 1993), when several N-S normal faults reactivated previous thrusts. Between 12 and $8 \mathrm{Ma}$, several NE-SW thrusts initiated: the Muli fault in the Yalong margin (Pitard et al., submitted), the Wulong fault in the southern LMS (Cook, 2013) and the Beichuan fault in the central LMS (Godard et al., 2009) (Figure 12d). In the two first cases, this implies a late activation of internal faults.

\section{Conclusions}

Detailed field observations along the Jinhe-Qinghe thrust belt and low-temperature thermochronology (AFT and AHe dating) from the hanging wall of the Nibi thrust, branch of the JQTB yield new constraints on the amount and timing of thrusting in southeastern Tibet. The structure analysis shows that the JQTB is a post-Eocene thrust with several branches, with total apparent vertical offset on the order of $\sim 0.6$ to $3.6 \mathrm{~km}$. The pseudo-elevation-age profile and QTQt modeling of the Baishagou granite show that fast exhumation occurred between 20$15 \mathrm{Ma}$ in the hanging wall of the Nibi thrust at a rate of $\sim 0.42 \mathrm{~km} / \mathrm{Myr}$ corresponding to $\sim 1.7$ $2.4 \mathrm{~km}$ of total exhumation. Thrusting movement of JQTB was most probably responsible for this rapid exhumation and created significant relief in SE Tibet during the Miocene. 
535 When considering previous studies, it appears that Cenozoic exhumation and relief creation in 536 southeastern Tibet does not follow a simple pattern that could be explained by a single 537 mechanism. Building from relict reliefs from previous tectonic events (i.e., Triassic and 538 Cretaceous), at least three stages of Cenozoic shortening and relief creation have to be invoked. 539 The first stage was marked by Eocene NE-SW compression at least partly coeval with the

540 sedimentation of the Eocene sediments. The second stage during the Late Oligocene to Early 541 Miocene corresponds to an NW-SE to E-W compression yielding to thrusting in the LMS, and 542 the Yulong thrust belt. The activity of the JQTB is posterior to that event, corresponding to a 543 southeastern migration of the high plateau through time. A third stage corresponds to the 544 activation of left-lateral strike-slip faults such as the Xianshuihe fault and the re-activation of 545 thrusts such as the Beichuan and Wulong faults in the LMS and the Muli thrust. The precise 546 interaction between thrusting and fast river erosion driven by Miocene monsoon strengthening 547 as documented around 11-8 Myr ago (An et al., 2001; Zachos et al., 2001; Allen et al., 2012) 548 has not been deciphered yet, but Oligocene - Miocene thrusting appears to explain most of the 549 present-day relief in southeastern Tibet.

\section{Data Availability}

551 All the data documented are listed in the references or archived in Figshare repository 552 (10.6084/m9.figshare.13148498).

\section{Acknowledgments}

554 We thank Kerry Gallagher for proving us the new version of modeling software and the 555 guidance of QTQt modeling. We are also grateful to Andrew Gleadow for the helpful 556 suggestions about the fission track dating based on LA-ICP-MS. This work is funded by the 557 National Science Foundation of China (41672195). We thank two anonymous reviewers that 558 provided constructive comments on an early version of the manuscript. 


\section{REFERENCES}

Airaghi, L., de Sigoyer, J., Guillot, S.,Robert, A., Warren, C. J., Deldicque, D., 2018. The Mesozoic along-strike tectonometamorphic segmentation of Longmen Shan (eastern Tibetan plateau). Tectonics 37, 4655-4678. https://doi.org/10.1029/2018TC005005.

Allen, C.R., Luo, Z.L., Qian, H, Wen, X.Z., Zhou, H.W., Huang, W.S., 1991. Field study of a highly active fault zone: the Xianshuihe fault of southwestern China. Geological Society of America Bulletin 103, 1178-1199. https://doi.org/10.1130/00167606(1991)103<1178:FSOAHA>2.3.CO;2.

Allen, M.B., \& Armstrong, H.A., 2012. Reconciling the Intertropical Convergence Zone, Himalayan/Tibetan tectonics, and the onset of the Asian monsoon system. Journal of Asian Earth Sciences 44, 36-47. https://doi.org/10.1016/j.jseaes.2011.04.018.

An, Z.S., Kutzbach, J.E., Prell, W.L., Porter, S.C., 2001. Evolution of Asian monsoons and phased uplift of the Himalaya-Tibetan plateau since late Miocene times. Nature 411, 6266. https://doi.org/10.1038/35075035.

Botsyun, S., Sepulchre, P., Donnadieu, Y., Risi, C., Licht, A., Rugenstein, J.K.C., 2019. Revised paleoaltimetry data show low Tibetan Plateau elevation during the Eocene. Science 363, 946. https://doi.org/10.1126/science.aaq1436.

Braun J., 2002. Quantifying the effect of recent relief changes on age-elevation relationships. Earth and Planetary Science Letters 200, 331-343. https://doi.org/10.1016/S0012$\underline{821 X(02) 00638-6 .}$.

Burchfiel, B. C., Chen, Z. L., Liu, Y. P., Royden, L. H., 1995. Tectonics of the Longmen Shan and adjacent regions, central China. International Geology Review 37, 661-735. https://doi.org/10.1080/00206819509465424.

Bureau of Geology and Mineral Resources of Sichuan Province (map G47-06, G47-12, G4801, H47-36, H48-31, scale 1:200,000), 1991. Regional geology of Sichuan Province, Geological Publishing House, Beijing.

Bureau of Geology and Mineral Resources of Yunnan Province (map G47-11, scale 1:200,000), 1990. Regional Geology of Yunnan Province, Geological Publishing House, Beijing.

Cao, K., Wang, G.C., Leloup, P. H., Mahéo, G., Xu, Y.D., van der Beek, P. A., et al., 2019. Oligocene-Early Miocene topographic relief generation of southeastern Tibet triggered by thrusting. Tectonics 38 (1), 374-391. https://doi.org/10.1029/2017TC004832.

Cao, K., Leloup, P.H., Wang, G.C., Liu, W., Mahéo, G., Shen, T.Y., et al., 2020. Thrusting, exhumation, and basin fill on the western margin of the South China block during the India-Asia collision. Geological Society of America Bulletin https://doi.org/10.1130/B35349.1.

Chung, S.-L., Lo, C.-H., Lee, T.-Y., Zhang, Y., Xie, Y., Li, X., et al., 1998. Diachronous uplift of the Tibetan plateau starting 40 Myr ago. Nature 394 (6695), 769-773. https://doi.org/10.1038/29511.

Chung, S.-L., Chu, M.-F., Zhang, Y., Xie, Y., Lo, C.-H., Lee, T.-Y., Wang, Y., 2005. Tibetan tectonic evolution inferred from spatial and temporal variations in post-collisional 
https://doi.org/10.1016/j.earscirev.2004.05.001.

601

602

603

604

605

606

607

608

609

610

611

612

613

614

615

616

617

618

619

620

621

622

623

624

625

626

627

628

629

630

631

632

633

634

635

636

Clark, M.K., \& Royden, L.H., 2000. Topographic ooze: building the eastern margin of Tibet by lower crustal flow. Geology 28, 703-706. https://doi.org/ 10.1130/00917613(2000)28<703:TOBTEM $>2.0$. CO;2.

Clark, M.K., House, M.A., Royden, L.H., Whipple, K.X., Burchfiel, B.C., Zhang, X., Tang, W., 2005. Late Cenozoic uplift of southeastern Tibet. Geology 33, 525-528. https://doi.org/10.1130/G21265.1.

Clift, P.D., 2006. Controls on the erosion of Cenozoic Asia and the flux of clastic sediment to the ocean. Earth and Planetary Science Letters 241, 571-580. https://doi.org/ 10.1016/j.eps1.2005.11.028.

Clift, P.D., Wan, S.M., Blusztajn, J., 2014. Reconstructing chemical weathering, physical erosion and monsoon intensity since $25 \mathrm{Ma}$ in the northern South China Sea: A review of competing proxies. Earth-Science Reviews $1302014 \quad 86-102$. https://doi.org/ 10.1016/j.earscirev.2014.01.002.

Cook, K. Royden, L., L. H., Burchfiel, B. C., Lee, Y. H., Tan, X., 2013. Constraints on Cenozoic tectonics in the southwestern Longmen Shan from low-temperature thermochronology, Lithosphere 5(4), 393-406. https://doi.org/ 10.1130/L263.1.

Ehlers, T.A., 2005. Crustal thermal processes and the interpretation of thermochronometer data. Rev. Mineral. Geochem. 58, 315-350. https://doi.org/10.2138/rmg.2005.58.12.

Farley K.A., 2002. (U-Th)/He dating: Techniques, calibrations, and applications. Rev Mineral Geochem. 47(1):819-844. https://doi.org/10.2138/rmg.2002.47.18.

Farley, K. A., Shuster, D. L. Ketcham, R. A., 2011. U and Th zonation in apatite observed by laser ablation ICPMS, and implications for the (U-Th)/He system. Geochimica et Cosmochimica Acta 75, 4514-4530. https://doi.org/10.1016/j.gca.2011.05.020.

Gallagher, K., 2012. Transdimensional inverse thermal history modeling for quantitative thermochronology. Journal of Geophysical Research 117, B02408. https://doi.org/ $\underline{10.1029 / 2011 \mathrm{JB} 008825 .}$

Gao, L., Yang, Z.Y., Tong, Y.B., Wang, H., An, C.Z., Zhang, H.F., 2017. Cenozoic clockwise rotation of the Chuan Dian Fragment, southeastern edge of the Tibetan Plateau: Evidence from a new paleomagnetic study. Journal of Geodynamics 112 (2017), 46-57. https://doi.org/10.1016/j.jog.2017.10.001.

Ge Y.K., Liu-Zeng, J., Zhang J.Y., Wang W., Tian Y.T., Fox M., et al., 2020. Spatio-temporal variation in rock exhumation linked to large-scale shear zones in the southeastern Tibetan Plateau. Science China Earth Sciences 63, 512-532. https://doi.org/10.1007/s11430-0199567-y.

Godard, V., Pik, R., Lave, J., Cattin, R., Tibari, B., de Sigoyer, J., Pubellier, M., Zhu, J., 2009, Late Cenozoic evolution of the central Longmen Shan, eastern Tibet: Insight from (U- 
Gourbet, L., Leloup, P. H., Paquette, J.-L., Sorrel, P., Maheo, G., Wang, G.C., et al., 2017.

640

641 Reappraisal of the Jianchuan Cenozoic basin stratigraphy and its implications on the SE Tibetan plateau evolution. Tectonophysics 700-701, 162-179. https://doi.org/10.1016/j.tecto.2017.02.007.

Hoke, G.D., Liu-Zeng, J., Hren, M.T., Wissink, G.K., Garzione, C.N., 2014. Stable isotopes reveal high southeast Tibetan plateau margin since the Paleogene. Earth and Planetary Science Letters 394, 270-278. https://doi.org/10.1016/j.eps1.2014.03.007.

Horton, B.K., Yin, A., Spurlin, M.S., Zhou, J., Wang, J., 2002, Paleocene-Eocene syncontractional sedimentation in narrow, lacustrine-dominated basins of eastcentral Tibet: Geological Society of America Bulletin 114 (7), 771-786. https://doi.org/10.1130/0016-7606(2002)114<0771:PESSIN>2.0.CO;2.

Hu X.M., Garzanti, E., Wang, J.G., Huang, W.T., An, W., Webb, A., 2016. The timing of IndiaAsia collision onset - Facts, theories, controversies. Earth-Science Reviews 160, 264-299. https://doi.org/10.1016/j.earscirev.2016.07.014.

Kirby, E., Reiners, P. W., Krol, M. A., Whipple, K. X., Hodges, K. V., Farley, K. A., Chen, Z., 2002. Late Cenozoic evolution of the eastern margin of the Tibetan Plateau: Inferences from 40Ar/39Ar and (U-Th)/He thermochronology. Tectonics 21, 1001. https://doi.org/10.1029/2000TC001246.

Leloup, P. H., Lacassin, R., Tapponnier, P., Scharer, U., Zhong, D.L., Liu, X.H., et al., 1995. The Ailao Shan-Red River shear zone (Yunnan, China), Tertiary transform boundary of Indochina. Tectonophysics 251(1-4), 3-84. https://doi.org/10.1016/0040-1951(95)000704.

Leloup, P.H., Arnaud, N., Lacassin, R., Kienast, J., Harrison, T., Trong, T.T.P., et al., 2001. New constraints on the structure, thermochronology, and timing of the Ailao Shan-Red River shear zone, SE Asia. Journal of Geophysical Research 106, 6683-6732. https://doi.org/10.1029/2000JB900322.

Leloup, P. H., Tapponnier, P., Lacassin, R., 2007. Discussion on the role of the Red River shear zone, Yunnan and Vietnam, in the continental extrusion of SE Asia. Journal of the Geological Society, London, 164, 2007, pp. 1253-1260. https://doi.org/ 10.1144/001676492007-065.

Li, S.Y., Currie, B.S., Rowley, D.B., Ingalls, M., 2015. Cenozoic paleoaltimetry of the SE margin of the Tibetan plateau: constraints on the tectonic evolution of the region. Earth and Planetary Science Letters 432, 415-424. https://doi.org/10.1016/j.eps1.2015.09.044.

Liang, H.Y., Campbell, I.H., Allen, C.M., Sun, W.D., Yu, H.X., Xie, Y.W., Zhang, Y.-Q., 2007. The age of the potassic alkaline igneous rocks along the Ailao Shan-Red River shear zone: implications for the onset age of left-lateral shearing. The Journal of Geology 115, 231242. https://doi.org/10.1086/527459. 
Lin, T. H., Lo, C. H., Chung, S. L., Hsu, F. J., Yeh, M. W., Lee, T. Y., et al., 2009. 40Ar/39Ar dating of the Jiali and Gaoligong shear zones: Implications for crustal deformation around the eastern Himalayan syntaxis. Journal of Asian Earth Sciences 34(5), 674-685. https://doi.org/10.1016/j.jseaes.2008.10.009.

Liu-Zeng, J., Tapponnier, J.P., Gaudemer, Y., Ding, L., 2008. Quantifying landscape differences across the Tibetan plateau: implications for topographic relief evolution. Journal of Geophysical Research 113, F04018. https://doi.org/10.1029/2007JF000897.

Liu-Zeng, J., Zhang, J.Y., McPhillips, D., Reiners, P., Wang, W., Pik, R., et al., 2018. Multiple episodes of fast exhumation since Cretaceous in southeast Tibet, revealed by lowtemperature thermochronology. Earth and Planetary Science Letters 490, 62-76. https://doi.org/10.1016/j.eps1.2018.03.011.

Lu, Y. J., Kerrich, R., Cawood, P. A., McCuaig, T. C., Hart, C. J. R., Li, Z. X., et al. 2012. Zircon SHRIMP U-Pb geochronology of potassic felsic intrusions in western Yunnan, SW China: Constraints on the relationship of magmatism to the Jinsha suture. Gondwana Research 22(2), 737-747. https://doi.org/10.1016/j.gr.2011.11.016.

Molnar, P., \& Tapponnier, P., 1975. Cenozoic tectonics of Asia: effects of a continental collision. Science 189, 419-426. https://doi.org/ 10.1126/science.189.4201.419.

Nie, J., Ruetenik, G., Gallagher, K., Hoke, G., Garzione, C. N., Wang, W., et al. 2018. Rapid incision of the Mekong River in the middle Miocene linked to monsoonal precipitation. Nature Geoscience 11(12), 944-948. https://doi.org/10.1038/s41561-018-0244-z.

Ouimet, W., Whipple, K., Royden, L., Reiners, P., Hodges, K., Pringle, M., 2010. Regional incision of the eastern margin of the Tibetan plateau. Lithosphere 2, 50. https://doi.org/10.1130/L57.1.

Perrineau, A., 2010. Evolution morphologique et tectonique récente des marges NE et SE du plateau tibétain: Lien avec la dynamique des grands fleuves. Institut de Physique du Globe de Paris. pp. 421.

Reiners, P. W., \& Brandon, M. T., 2006. Using thermochronology to understand orogenic erosion. Annual Review of Earth and Planetary Sciences 34(1), 419-466. https://doi.org/10.1146/annurev.earth.34.031405.125202.

Replumaz, A., Lacassin, R., Tapponnier, P., Leloup, P. H., 2001. Large river offsets and PlioQuaternary dextral slip rate on the Red River fault (Yunnan, China). Journal of Geophysical Research 106(B1), 819-836. https://doi.org/10.1029/2000JB900135.

Roger, F., J. Malavieille, P. H. Leloup, S. Calassou, Z. Xu, 2004. Timing of granite emplacement and cooling in the Songpan-Garze Fold Belt (eastern Tibetan Plateau) with tectonic implications. Journal of Asian Earth Sciences 22(5), 465-481. https://doi.org/10.1016/S0137-9120(03)00089-0.

Roger, F., Jolivet, M. Malavieille, J., 2010. The tectonic evolution of the Songpan Garze^ (North Tibet). Journal of Asian Earth Sciences 39, 254-269. https://doi.org/10.1016/j.crte.2007.10.014. 
Royden, L. H., Burchfiel, B. C., King, R. W., Wang, E., Zhiliang, C., Feng, S., Yuping, L., 1997. Surface deformation and lower crustal flow in eastern Tibet. Science 276(5313), 788-790. https://doi.org/10.1126/science.276.5313.788.

Schärer, U., Zhang, L. S., Tapponnier, P., 1994. Duration of strike-slip movements in large shear zones: The Red River belt, China. Earth and Planetary Science Letters 126(4), 379397. https://doi.org/10.1016/0012-821X(94)90119-8.

Schildgen, T.F., \& van der Beek, P.A., 2019. The Application of Low-Temperature Thermochronology to the Geomorphology of Orogenic Systems. In M. G. Malusà and P. G. Fitzgerald (Eds.), Fission-Track Thermochronology and its Application to Geology (pp. 335-350). Springer Textbooks in Earth Sciences, Geography and Environment.

Schoenbohm, L.M., Burchfiel, B.C., Chen, L., 2006. Propagation of surface uplift, lower crustal flow, and Cenozoic tectonics of the southeast margin of the Tibetan plateau. Geology 34, 813-816. https://doi.org/10.1130/G22679.1.

Shen, T.Y., Wang G.C., Leloup, P. H., van der Beek, P., Bernet, M., Cao, K., Wang, A., Liu, C., Zhang K.X., 2016a. Controls on Cenozoic exhumation of the Tethyan Himalaya from fission-track thermochronology and detrital zircon $\mathrm{U}-\mathrm{Pb}$ geochronology in the Gyirong basin area, southern Tibet, Tectonics 35, 1713-1734. https://doi:10.1002/2016TC004149.

Shen, X.M., Tian, Y.T., Li, D.W., Qin, S.W., Vermeesch, P., Schwanethal, J., 2016 b. Oligocene-Early Miocene river incision near the first bend of the Yangze River: Insights from apatite (U-Th-Sm)/He thermochronology. Tectonophysics 687, 223-231. https://doi.org/10.1016/j.tecto.2016.08.006.

Shuster, D. L., Flowers, R. M. Farley, K. A., 2006. The influence of natural radiation damage on helium diffusion kinetics in apatite. Earth and Planetary Science Letters 249, 148-161. https://doi.org/10.1016/j.eps1.2006.07.028.

Si, G., Li, Y., \& Hou, Z., 2000, The Tertiary stratigraphy sequence of Yanyuan Basin in the southeastern margin of the Qinghai-Tibet Plateau, Earth Science Frontiers, 7, 304-305.

Spurlin, M.S., Yin, A., Horton, B.K., Zhou, J., Wang, J., 2005, Structural evolution of the Yushu-Nangqian region and its relationship to syncollisional igneous activity, east-central Tibet. Geological Society of America Bulletin 117 (9-10), 1293-1317. https://doi.org/10.1130/B25572.1.

Staisch, L.M., Niemi, N.A., Clark, M.K., Chang, H., 2016, Eocene to late Oligocene history of crustal shortening within the Hoh Xil Basin and implications for the uplift history of the $\begin{array}{lllll}\text { northern Tibetan } & \text { Plateau. } & \text { Tectonics } & 35 & \text { (4), 862-895. }\end{array}$ https://doi.org/10.1002/2015TC003972.

Su, T., Spicer, R.A., Li, S.H., Xu, H., Huang, J., Sherlock, S., Huang, Y.J., Li, S.F. et al., 2018. Uplift, climate and biotic changes at the Eocene-Oligocene transition in south-eastern Tibet. National Science Review 6(3), 495-504. https://doi.org/10.1093/nsr/nwy062.

Tang, M.Y., Liu-Zeng, J., Hoke, G. D., Xu, Q., Wang, W.T., Li, Z.F., et al., 2017. Paleoelevation reconstruction of the Paleocene-Eocene Gonjo basin, SE-central Tibet. Tectonophysics 712-713, 170-181. https://doi.org/10.1016/j.tecto.2017.05.018. 
Tapponnier, P., Zhiqin, X., Roger, F., Meyer, B., Arnaud, N., Wittlinger, G., Jingsui, Y., 2001. Oblique stepwise rise and growth of the Tibet plateau. Science 294(5547), 1671-1677. https://doi.org/10.1126/science.105978.

Tian, Y.T., Kohn, B.P., Gleadow, A.J., Hu, S.B., 2013. Constructing the Longmen Shan eastern Tibetan plateau margin: insights from low-temperature thermochronology. Tectonics 32 , 576-592. https://doi.org/10.1002/tect.20043.

Tian, Y.T., Kohn, B.P., Gleadow, A.J.W., Hu, S.B., 2014. A thermochronological perspective on the morphotectonic evolution of the southeastern Tibetan plateau. Journal of Geophysical Research 119, 676-698. https://doi.org/10.1002/2013JB010429.

Vermeesch, P., Seward D., Latkoczt, C., Wipf, M., Gunther D., Baur, H., 2007. Alpha-emitting mineral inclusions in apatite, their effect on (U-Th)/He ages, and how to reduce it. $\begin{array}{llll}\text { Geochimica et } & \text { 1737-1746. }\end{array}$ https://doi.org/10.1016/j.gca.2006.09.020.

Vermeesch, P., \& Tian, Y. T., 2014. Thermal history modelling: HeFTy vs. QTQt. Eart-Science Reviews 139, 279-290. https://doi.org/10.1016/j.earscirev.2014.09.010.

Wagner G., \& van den Haute P., 1992. Fission-track dating. Kluwer Academic Publishers, Dordrecht, Solid Earth Sciences Library. pp. 285.

Wallis, S., Tsujimori, T., Aoya, M., Kawakami, T., Terada, T., Suzuki, K., Hyodo, H., 2003. Cenozoic and Mesozoic metamorphism in the Longmenshan orogen: Implications for geodynamic models of eastern Tibet. Geology 31 (9), 745-748. https://doi.org/10.1130/G19562.1.

Wang, E., Burchfiel, B.C., Royden, L.H., Chen, L., Chen, J., Li, W., Chen, Z., 1998. The Cenozoic Xianshuihe-Xiaojiang, Red River, and Dali Fault Systems of southwestern Sichuan and central Yunnan, China. Spec. Pap., Geological Society of America Bulletin 327. 108 https://doi.org/10.1130/0-8137-2327-2.1.

Wang, E., \& Burchfiel, B.C., 2000. Late Cenozoic to Holocene deformation in southwestern Sichuan and adjacent Yunnan, China, and its role in formation of the southeastern part of the Tibetan Plateau. Geological Society of America Bulletin 112, 413-423. https://doi.org/10.1130/0016-7606(2000)112<413:LCTHDI >2.0.CO;2.

Wang, E., Kirby, E., Furlong, K., van Soest, M., Xu, G., Shi, X., Kamp, P., Hodges, K., 2012a. Two-phase growth of high topography in eastern Tibet during the Cenozoic. Nature. Geoscience 5, 640-645. https://doi.org/10.1038/ngeo1538.

Wang, G.C., Zhang, K.X., Xiang, S.Y., Wang, A., Cao, K. et al., 2014. Cenozoic geological map and guidebook of Tibet Plateau and its adjacent regions 1:1 500 000, 2014. China University of Geosciences Press, Wuhan, pp. 155.

Wang, H., Tian, Y., Liang, M., 2017. Late Cenozoic exhumation history of the Luoji Shan in the southeastern Tibetan Plateau: Insights from apatite fission-track thermochronology. Journal of the Geological Society 174, 883-891. https://doi.org/10.1144/jgs2017-005. 
Wang, S.F., Fang, X.M., Zheng, D.W., Wang, E., 2009. Initiation of slip along the Xianshuihe fault zone, eastern Tibet, constrained by $\mathrm{K} / \mathrm{Ar}$ and fission-track ages. International Geology Review 51(12), 1121-1131. https://doi.org/10.1080/00206810902945132.

Wang, S.F., Jiang, G.G., Xu, T.D., Tian, Y.T., Zheng, D.W., Fang, X.M., 2012b. The JinheQinghe fault-An inactive branch of the Xianshuihe-Xiaojiang fault zone, eastern Tibet. Tectonophysics 544-545, 93-102. https://doi.org/ 10.1016/j.tecto.2012.04.004.

Wang, Y., Zhang, B., Schoenbohm, L.M., Zhang, J., Zhou, R., Hou, J., Ai, S., 2016. Late Cenozoic tectonic evolution of the Ailao Shan-Red River fault (SE Tibet): Implications for kinematic change during plateau growth, Tectonics 35, 1969-1988, http://doi:10.1002/2016TC004229.

Wu G.L., Zhu C.Y., Wang G.C., Zhang P., 2019. Demarcation of the geomorphological boundaries of southeastern Tibet: implications for expansion mechanisms of the plateau edge. Seismology and Geology 2(41), 281-299 (in Chinese with English abstract). http:// doi.org/10.3969/j.issn.0253-4967.2019.02.003.

Wu, J., Zhang, K., Xu, Y., Wang, G., Garzione, C. N., Eiler, J., Leloup, P. H., et al., 2018, Paleoelevations in the Jianchuan Basin of the southeastern Tibetan Plateau based on stable isotope and pollen grain analyses. Palaeogeography, Palaeoclimatology, Palaeoecology 510, 93-108. https://doi.org/10.1016/j.palaeo.2018.03.030.

Xu, G., \& Kamp, P. J. J., 2000. Tectonics and denudation adjacent to the Xianshuihe fault, eastern Tibetan plateau: Constraints from fission track thermochronology. Journal of Geophysical Research 105(B8), 19,231-19,251. https://doi.org/10.1029/2000JB900159.

Yan, B., \& Lin, A., 2015. Systematic deflection and offset of the Yangtze River drainage system along the strike-slip Ganzi-Yushu-Xianshuihe fault zone, Tibetan Plateau. Journal of Geodynamics 87, 13-25. http://doi/10.1016/j.jog.2015.03.002.

Yang, R., Fellin, M.G., Herman, F., Willett, S.D., Wang, W., Maden, C., 2016. Spatial and temporal pattern of erosion in the three rivers region, southeastern Tibet. Earth and Planetary Science Letters 433, 10-20. https://doi.org/10.1016/j.eps1.2015.10.032.

Zachos, J., Pagani, M., Sloan, L., Thomas, E., Billups, K., 2001. Trends, rhythms, and aberrations in global climate $65 \mathrm{Ma}$ to present. Science 292, 686-693. https://doi.org/10.1126/science.1059412.

Zhang, B., Zhang, J.J., Chang, Z.F., Wang, X.X., Cai, F.L., Lai, Q.Z., 2012. The Biluoxueshan transpressive deformation zone monitored by synkinematic plutons, around the eastern $\begin{array}{llll}\text { Himalayan } & \text { syntaxis. } & \text { Tectonophysics } & 574-575,\end{array}$ https://doi.org/10.1016/j.tecto.2012.08.017.

Zhang, H.P., Oskin, M. E., Liu-Zeng, J., Zhang, P.Z., Reiners, P. W., Xiao, P., 2016. Pulsed exhumation of interior eastern Tibet: Implications for relief generation mechanisms and the origin of high-elevation planation surfaces. Earth and Planetary Science Letters 449, 176-185. https://doi.org/10.1016/j.eps1.2016.05.048. 
831 Zhang, P. Z., Shen, Z., Wang, M., Gan, W. J., Burgmann, R., Molnar, P., et al., 2004.

832 Continuous deformation of the Tibetan Plateau from global positioning system data.

833 Geology 32(9), 809-812. https://doi.org/10.1130/G20554.1.

834 Zhang, Y. Z., Replumaz, A., Wang, G. C., Leloup, P. H., Gautheron, C., Bernet, M., et al., 835 2015. Timing and rate of exhumation along the Litang fault system, implication for fault 836 reorganization in southeast Tibet. Tectonics 34, 1219-1243. 837 https://doi.org/10.1002/2014TC003671.

838 Zhang, Y. Z., Replumaz, A., Leloup, P. H., Wang, G. C., Bernet, M., van der Beek, P., et al., 839 2017. Cooling history of the Gongga batholith: Implications for the Xianshuihe fault and 840 Miocene kinematics of SE Tibet. Earth and Planetary Science Letters 465, 1-15. $841 \quad$ https://doi.org/10.1016/j.eps1.2017.02.025.

842 Zheng, H. B., Clift, P. D., He, M. Y., Bian, Z. X., Liu, G. Z., Liu, X. C., Xia L., et al., 2020. 843 Formation of the First Bend in the late Eocene gave birth to the modern Yangtze River, $844 \quad$ China. Geology 48. https://doi.org/10.1130/G48149.1. 


\section{Figures (1-11) \\ 2 Figure 1}

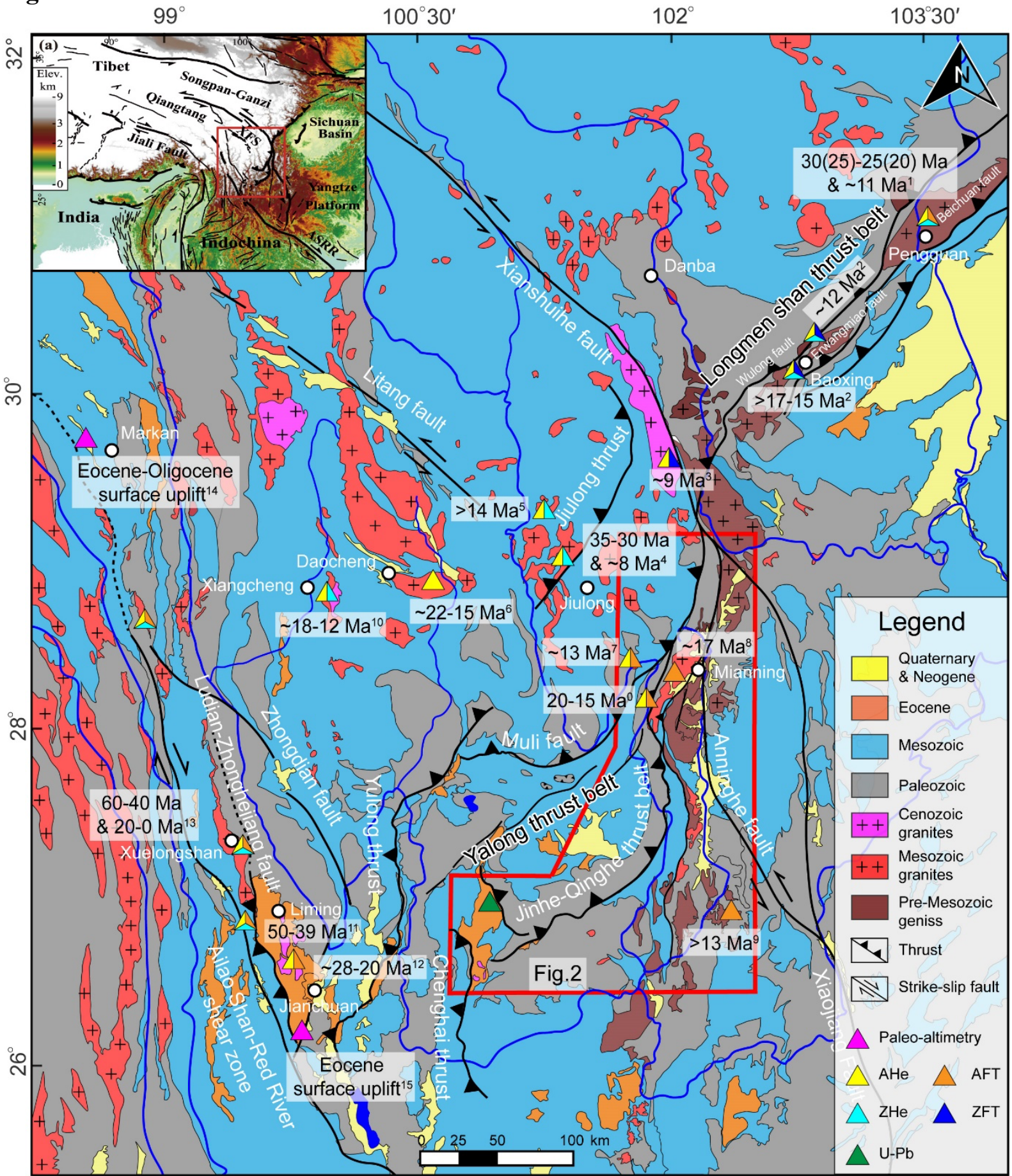

Fig. 1. Simplified geology and topography of southeastern Tibet, with major faults (modified after Leloup et al., 1995; Zhang et al.,2017; Cao et al., 2019). The inset in the upper left corner shows the location of southeastern Tibet. The triangle symbols denote accelerated exhumation phases derived from low-temperature thermochronology in southeastern Tibet: $0=$ This study, $1=$ E. Wang et al. (2012), $2=$ Cook et al. (2013), $3=$ Zhang et al. (2017), $4=$ Zhang et al. (2016), $5=$ Ouimet et al. (2010), $6=$ Tian et al. (2014), $7=$ Clark et al. (2005), $8=\mathrm{S}$. Wang et al. (2012), $9=$ Wang et al. (2017), $10=$ Gourbet et al. (2020), $11=$ Cao et al. (2020), $12=$ Cao et al. (2019), $13=$ Liu et al. (2018), $14=$ Su et al. (2018), $15=$ Hoke et al. (2014). 

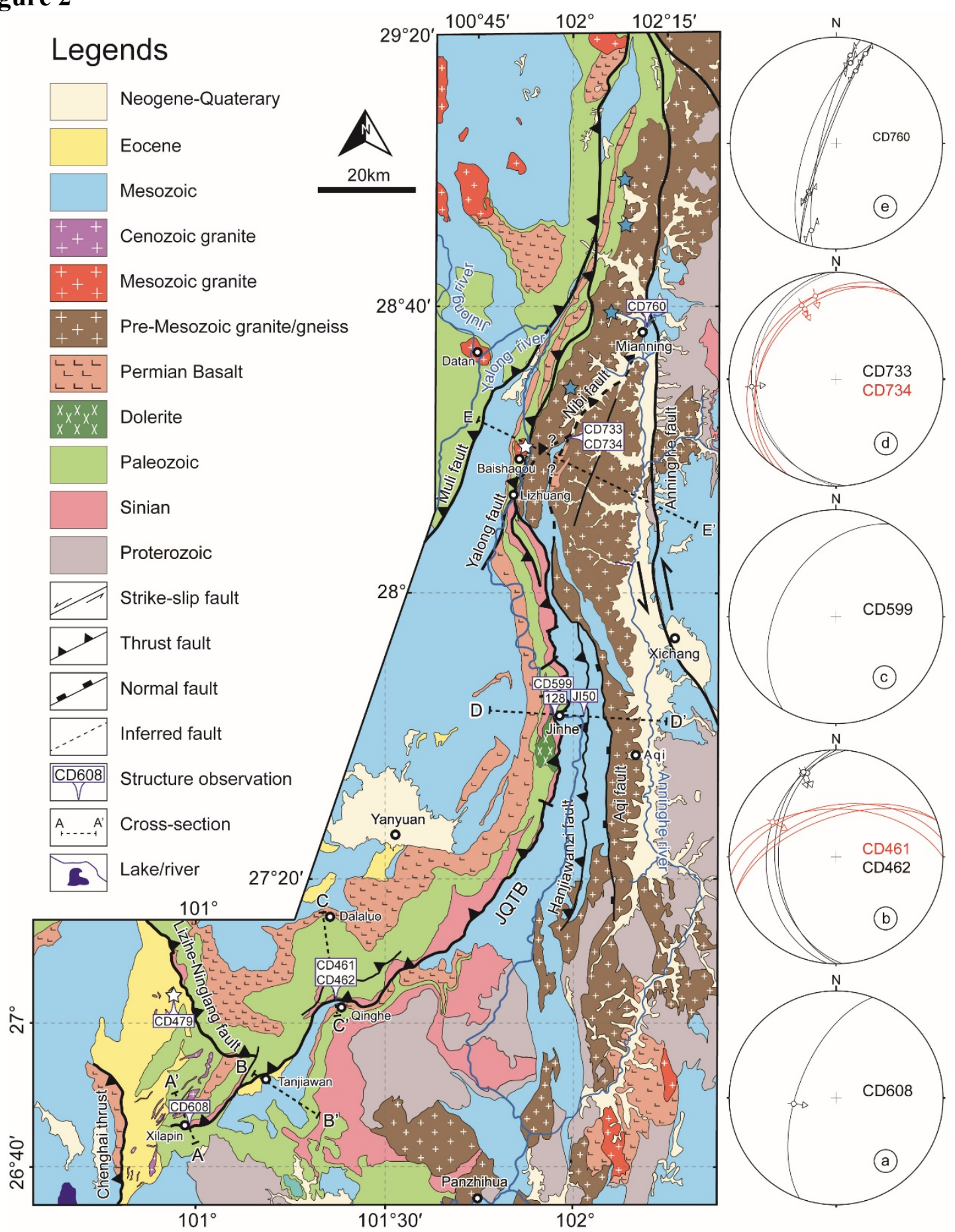

Fig. 2. Geological map of the Jinhe-Qinghe Thrust Belt based on BGMR Yunnan (1990), BGMR Sichuan (1991), S. Wang et al. (2012), and our new field observations. See Figure 1 for the location. A-e are the stereoplots shown of the Jinhe-Qinghe thrust belt at sites CD608, CD461 and CD462, CD508, CD733 and CD734, CD760, and CD759, from south to north, respectively. The locations of cross-sections A-A', B-B', C-C', D-D', E-E', and corresponding outcrops pictures are provided in Figures 3-7. The blue star denotes the AFT samples' locations in S. Wang et al. (2012). The white stars denote the sample locations in this study. 
Figure 3
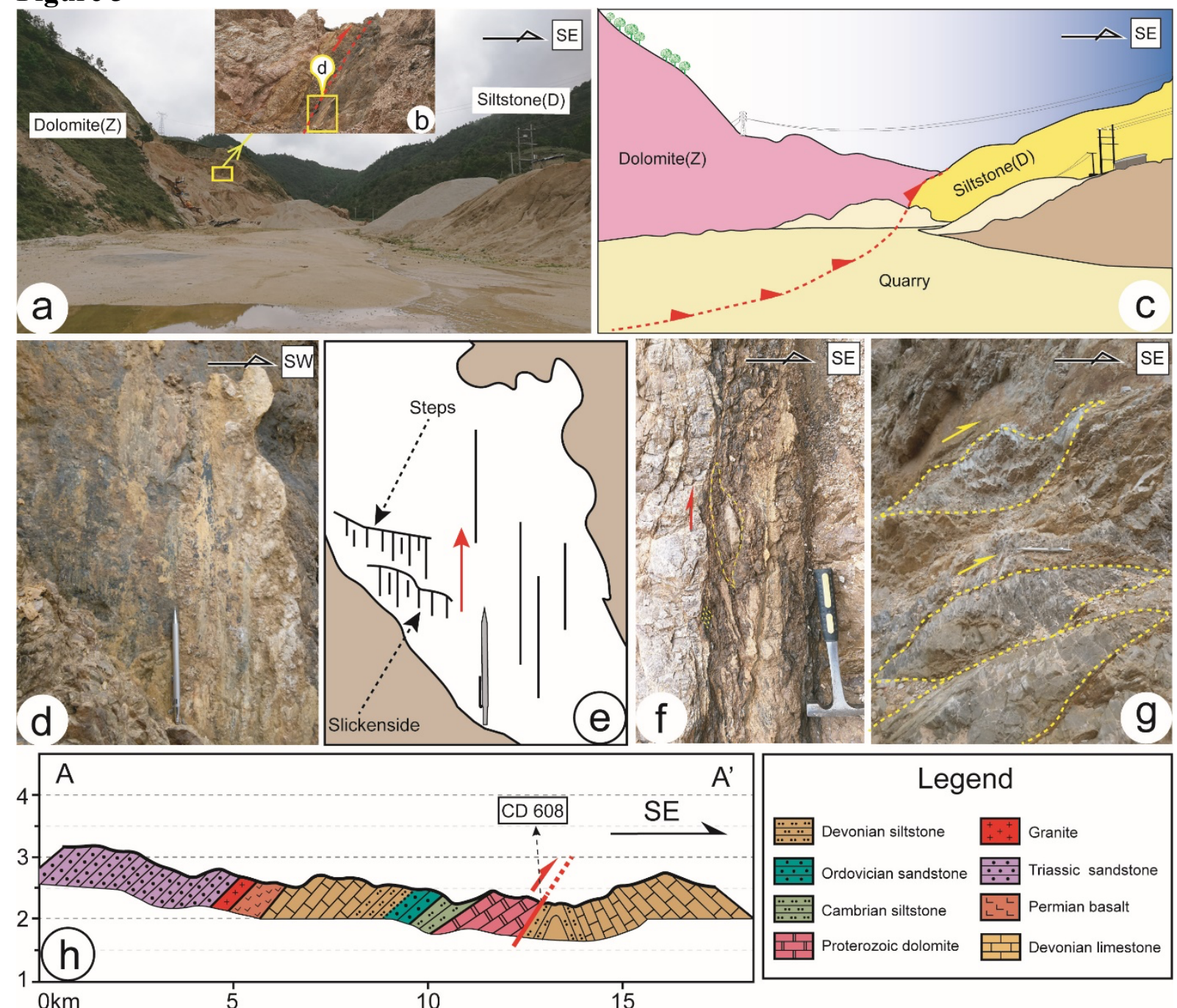

Fig. 3 Field observations in the Xilaping area. (a) Site CD608 picture with Sinian (Z) dolomite 25 on the left and Devonian (D) sediments on the right. (b) Damage zone in the dolomite. (c) Sketch corresponding to Figure 3a. (d) Close up of the fault plane with slickensides indicating 27 thrust motion (see location in Figure 3b). (e) Sketch corresponding to Figure 3e. (f) and (g) 28 Asymmetric dolomitic lenses compatible with the reverse motion of the JQTB. (h) Cross29 section in the Xilaping area perpendicular to the strike of the fault. See Figure 2 for location. 30 Vertical exaggeration is $2 \mathrm{x}$. 

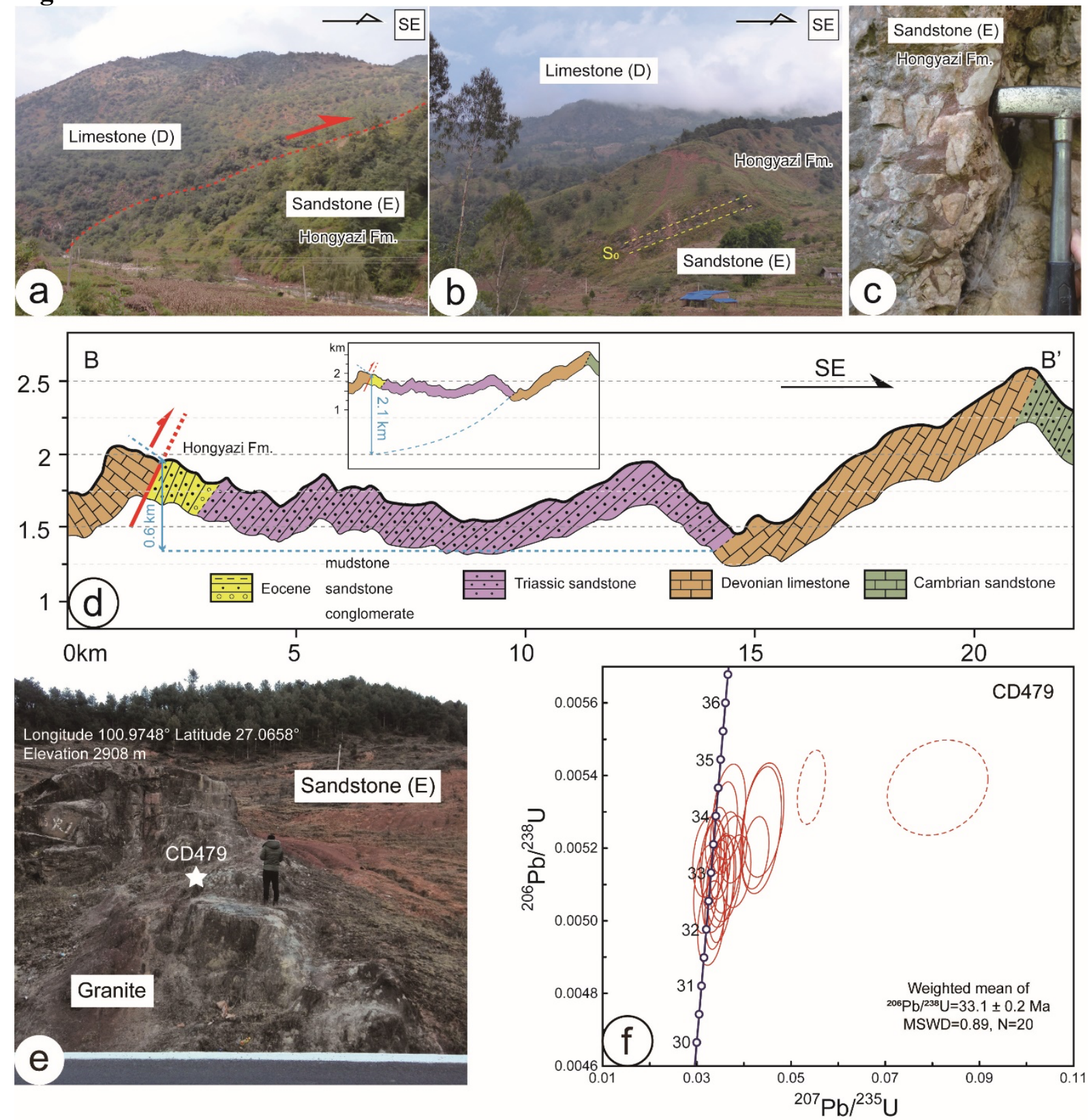

Fig. 4 Field observations in Tanjiawan and Ninglang. (a, b) Landscape pictures of the NW boundary of the Tanjiawan Basin showing the Devonian limestone thrusted on top of the Eocene sandstone. (c) Conglomerates with limestone pebbles at the bottom of the Hongyazi Fm. (d) Cross-section across the Tanjiawan Eocene basin. See Figure 2 for location. Vertical exaggeration is $3 \mathrm{x}$. Inset: estimate of the maximum apparent vertical offset. (e) Picture of site CD479 where granite is intrusive into sediments (Ninglang Fm.). (f) Concordia plot of Zircon $\mathrm{U}-\mathrm{Pb}$ data of the granite intrusion shown in (e) (sample CD479). 

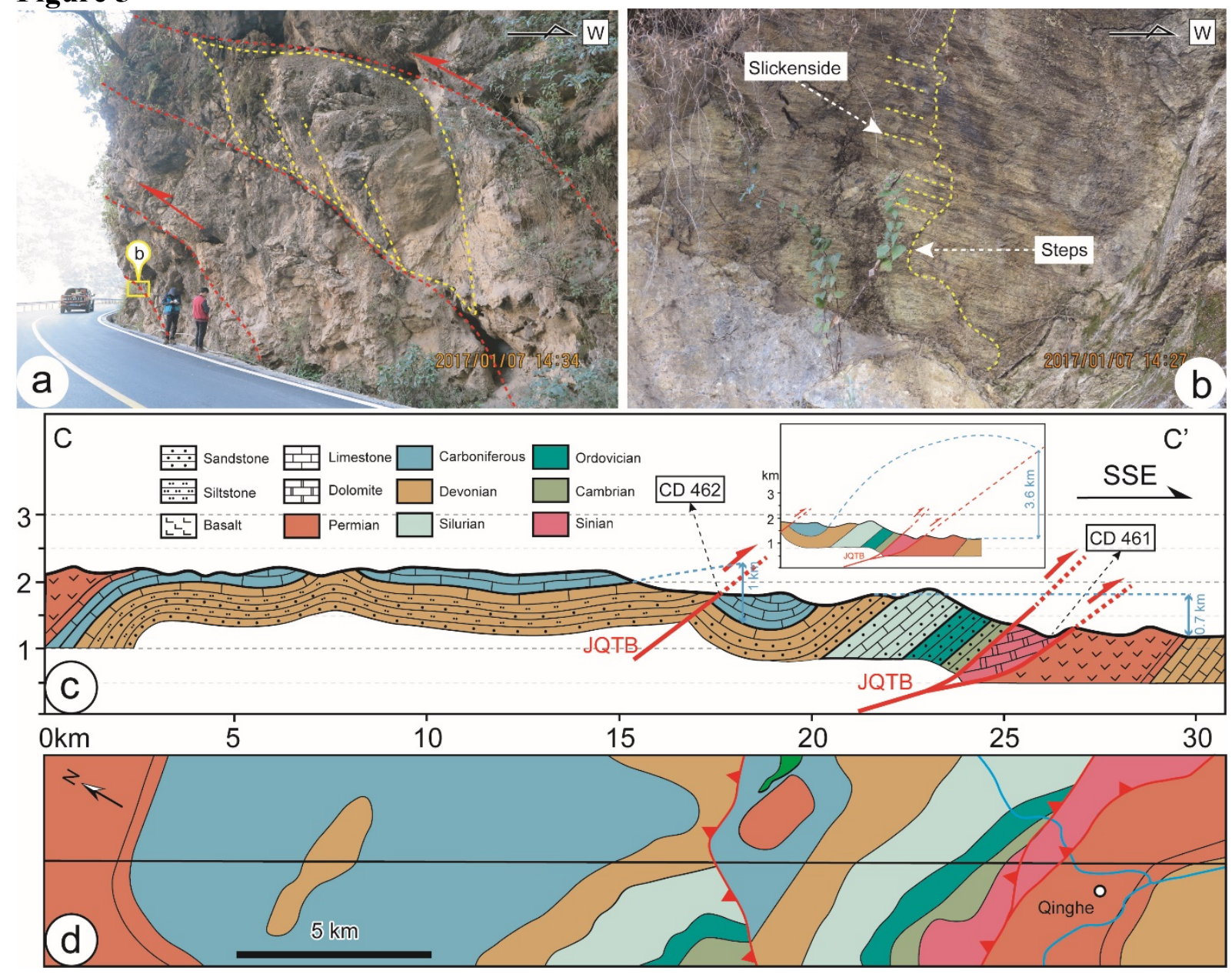

44 Fig. 5 Field observations along the Qinghe-Dalaluo cross-section. (a) Outcrop of a series of 45 minor faults at site CD462. (b) Slickensides and steps developed in the Devonian limestone. (c) 46 Qinghe-Dalaluo cross-section. See Figure 2 and 5d for location. Vertical exaggeration is 2x. 47 Inset: estimate of the maximum apparent vertical offset. (d) Geological map of the Qinghe48 Dalaluo cross-section. Black line is Fig. 5c cross-section trace. Mapping is based on Geol. map 49 G47-12 and this study. 

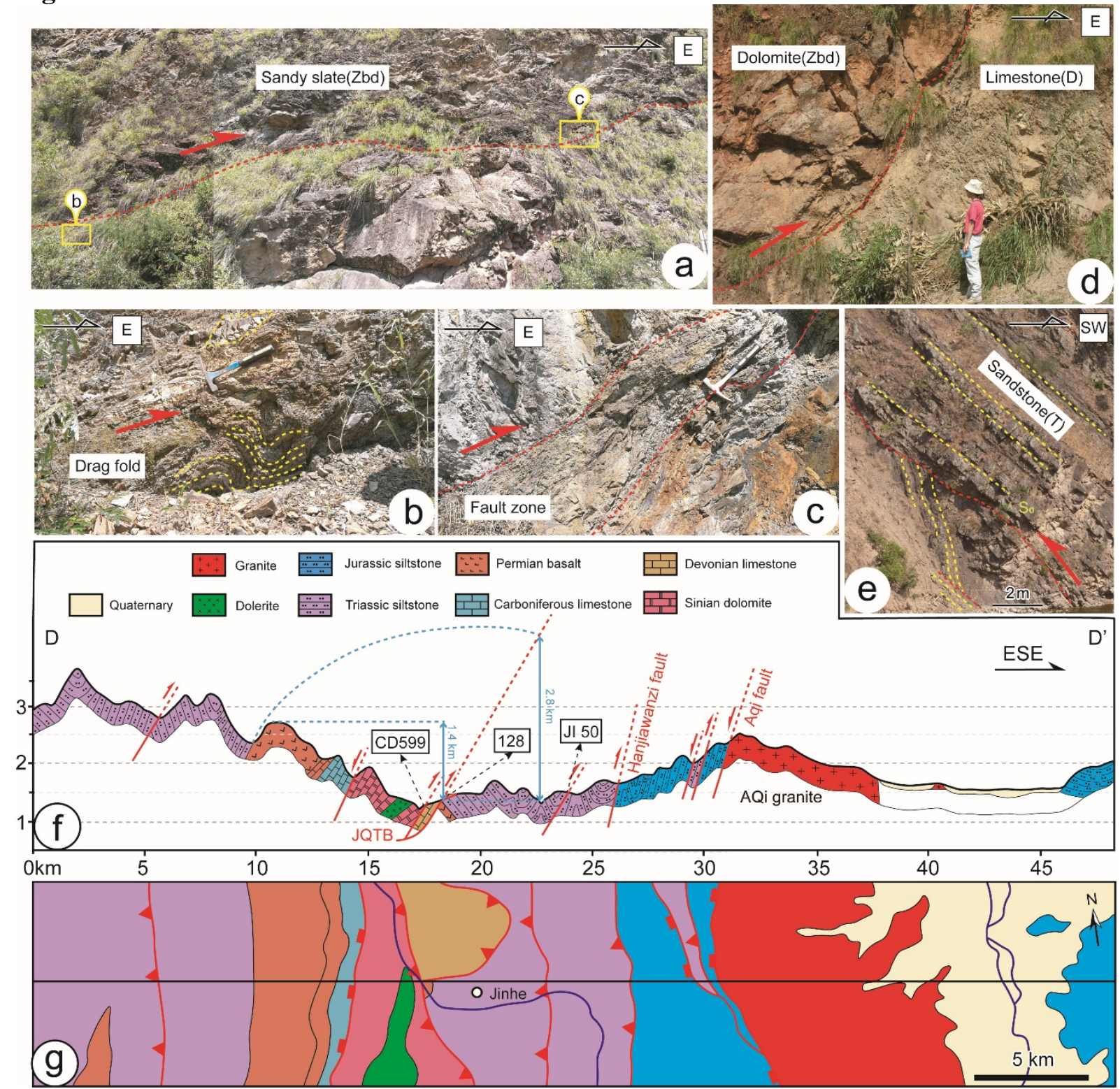

53 Fig. 6 Field observations along the Jinhe cross-section. (a)-(c) Outcrops of the fault zone

54 showing drag fault in Sinian dolomite near the Jinhe bridge (site CD599). (d) site 128. Outcrop of Sinian (Zbd and gabbros) thrusted above Upper Permian basalts. (e) Thrust fault within

56 Triassic siltstones at site JI50. (f) Jinhe cross-section. See Figure 2 and $6 \mathrm{~g}$ for location. Vertical

57 exaggeration is 2x. (g) Geological map of the Jinhe cross-section. Black line is Fig. 6f crosssection trace. Mapping is based on Geol. map G47-06 and this study. 

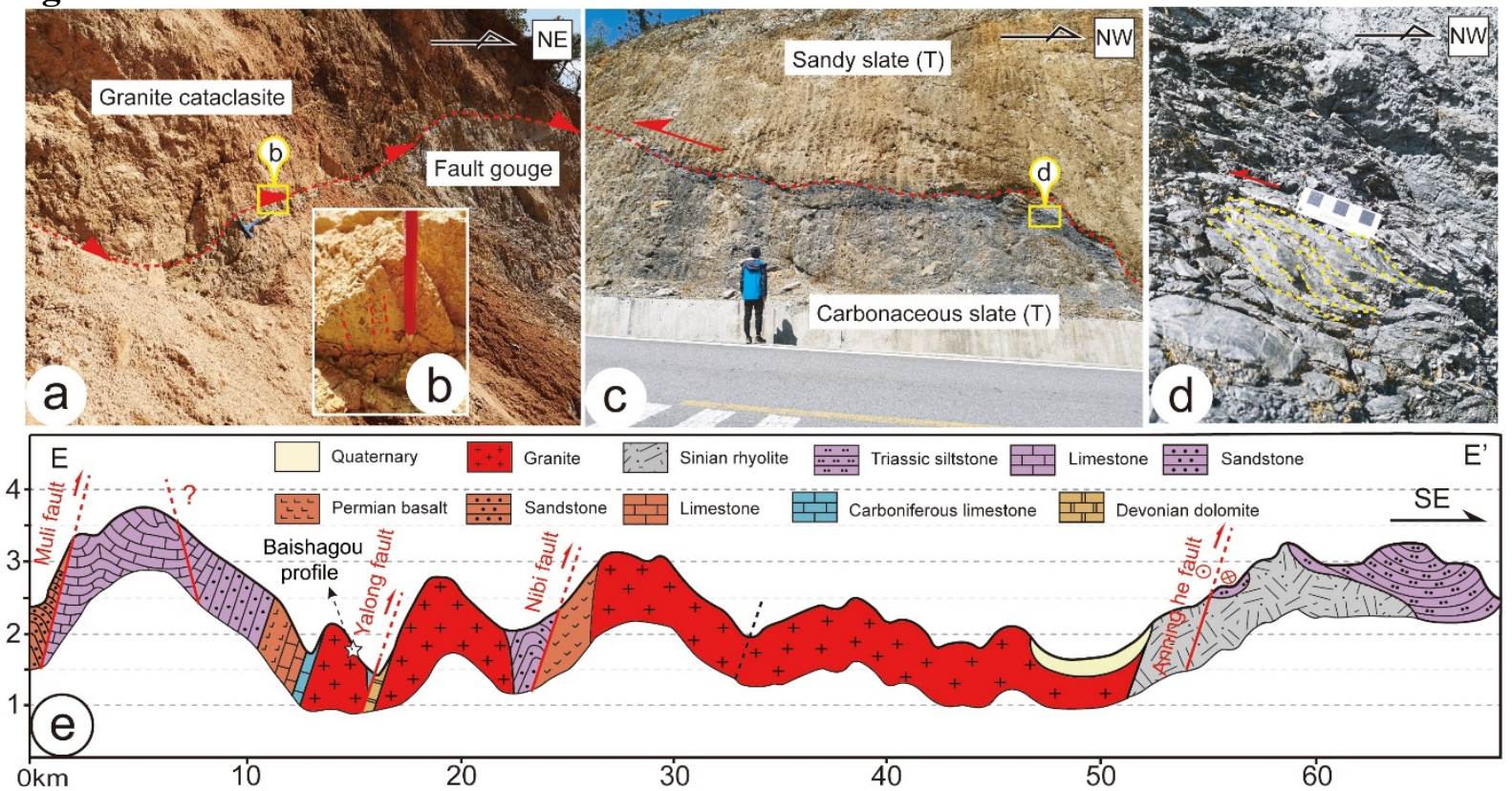

61

Fig. 7 Field observations along the Mianning-Yalong section. (a-b) site CD733. Cataclastic

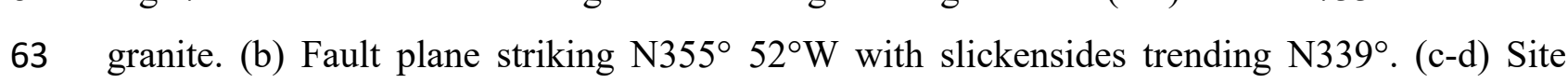

64 CD733b showing thrusting of granite on top of Triassic slate. (d) Triassic sediments are strongly

65 schistosed with slickenside trending N335 . (e-f) CD734 Outcrop of the contact between sandy

66 slate and carbonaceous slate at the site. (f) S-C fabrics in carbonaceous slate near the structure

67 contact. (i) Mianning-Yalong cross-section. See Figure 2 for the location. Vertical exaggeration 68 is $3 \mathrm{x}$. 
Figure 8
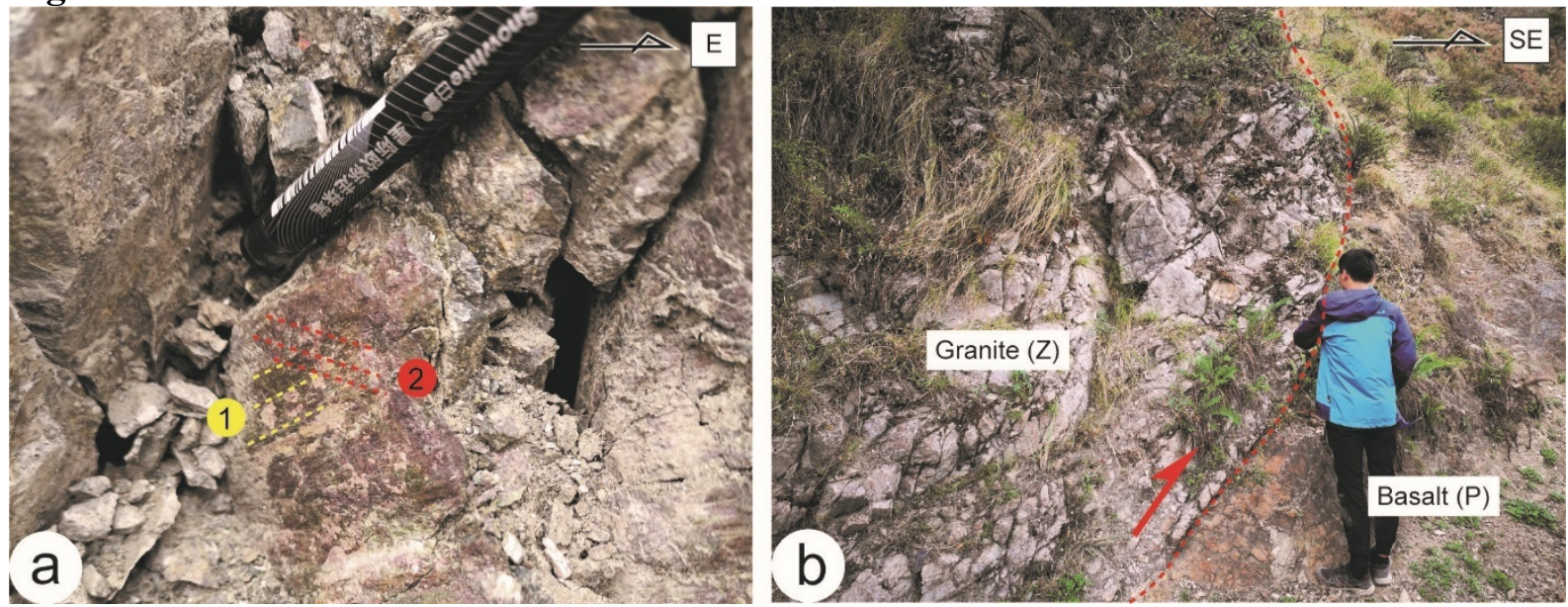

72 Fig. 8 Field observations around the Mianning area of site CD760. (a) two groups of 73 slickensides on the fault plane. Fault plane striking $\mathrm{N} 20^{\circ} 80^{\circ} \mathrm{W}$ with slickensides trending $74 \mathrm{~N} 350^{\circ}$ cut by another one trending N215 . (b) Structural contact between Sinian granite and 75 Permian basalt at site CD760. 

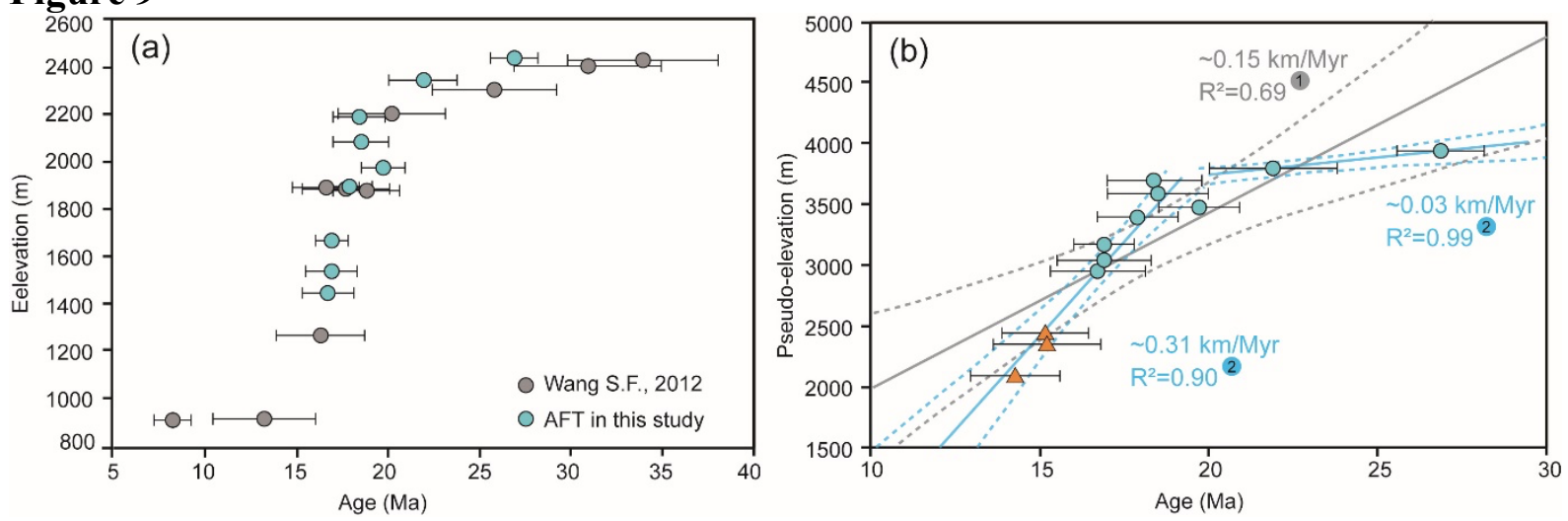

Fig. 9 AFT and AHe age elevation relationships (a) AFT age vs elevation plot. Data from S.

80 Wang et al., (2012) and this study. (b) AFT and AHe age vs pseudo-elevation profile (see text

81 for details). Data from this study. Two fits to the data are proposed: a single linear regression

82 array corresponding to a stable exhumation history, presented by gray lines (model 1); and two

83 arrays with a break in slope at $\sim 19$ Ma corresponding to two exhumation episodes model,

84 presented by blue lines (model 2). The solid lines are the least-squares regression relationships

85 of the samples, and the dashed lines represent the $95 \%$ confidence intervals. 

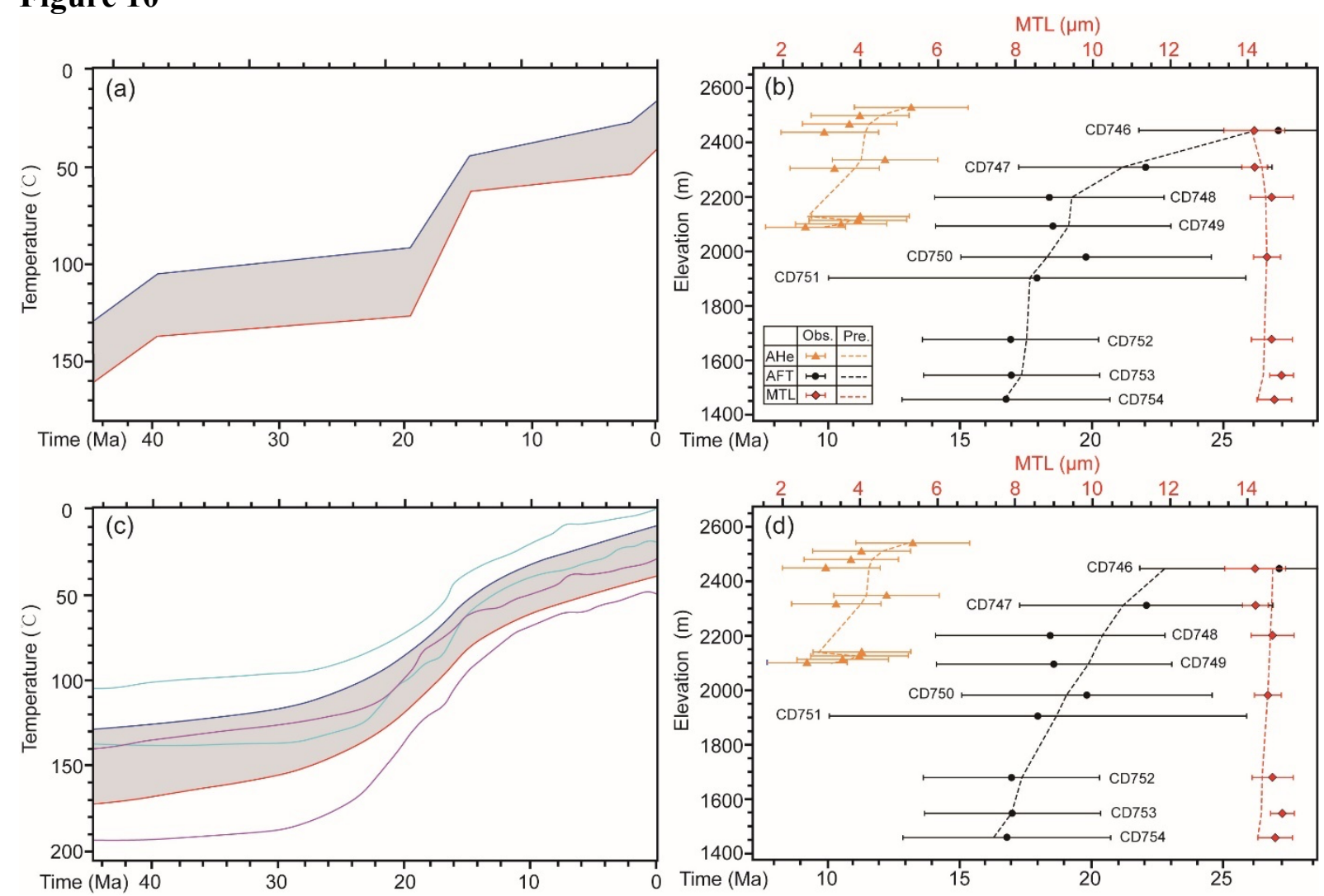

88 Fig. 10 Cooling history of the Baishagou vertical profile based on QTQt inverse modeling. (a)

89 and (c) Cooling history derived from the maximum likelihood model and the expected model, 90 respectively. (b) and (d) Comparison between the observed and predicted values for all samples 91 in the profile (single-grain ages for AHe and central ages for AFT). For the highest elevation 92 sample, the thermal history is plotted by the blue curve and the $95 \%$ credible intervals are drawn 93 in cyan. For the lowest elevation sample, the thermal history is plotted by the red curve and the $9495 \%$ credible intervals are drawn in magenta. Intermediate sample thermal histories are shown 95 in the grey area. MTL=mean track length 


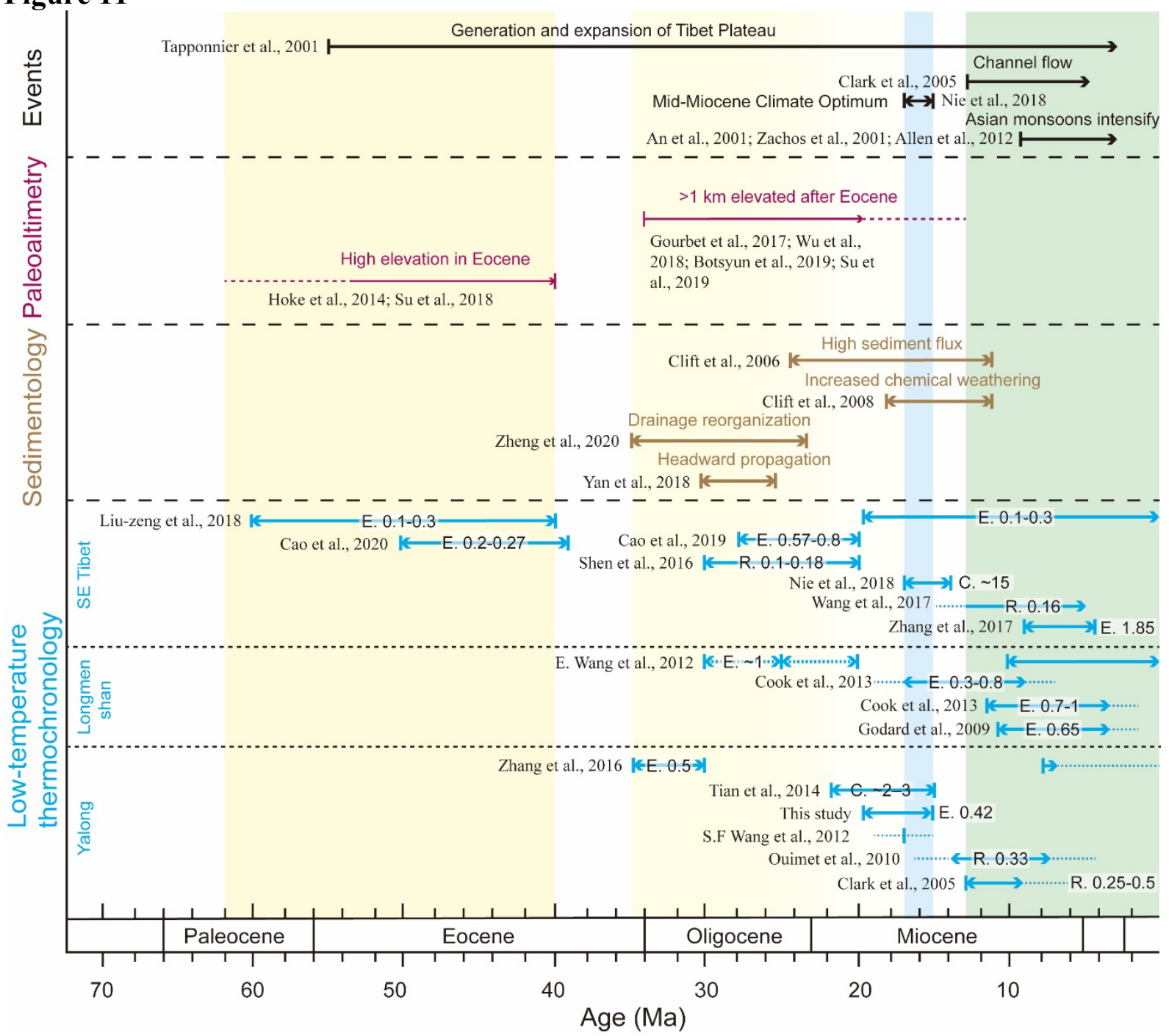

Fig. 11 Regional compilation of fast cooling/exhumation events with respect to paleo-altimetry and sediment flux in the South China Sea. Low-temperature thermochronology studies are derived from age-elevation profiles (see Figure 1 for localization) in southeastern Tibet. E. = exhumation rate, $\mathrm{km} / \mathrm{Myr}$; R. =river incision rate, $\mathrm{km} / \mathrm{Myr}$; C. $=$ cooling rate, ${ }^{\circ} \mathrm{C} / \mathrm{Myr}$. The yellow zones indicate the uplift events resulting from the southeast extrusion of Tibetan Plateau and its corresponding fast exhumation, sedimentary records and increase in paleo-elevation.

105 The blue rectangle indicates the Mid-Miocene climate optimum. The green rectangle indicates Late Miocene river incision which has been interpreted as due to lower crustal flow. 

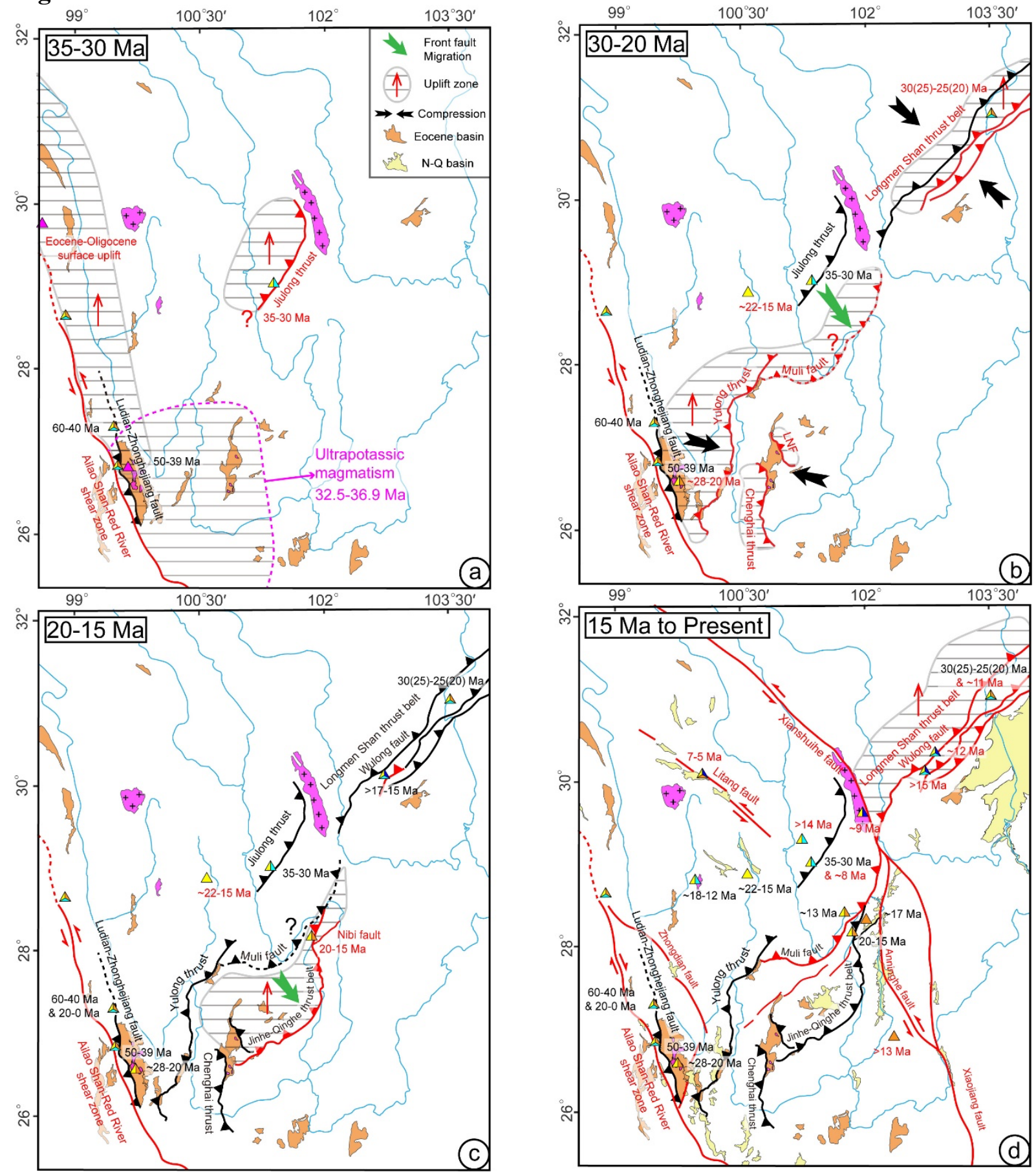

Fig. 12 Late Eocene to present evolution of the southeastern Tibetan Plateau during the

111 southeastward extrusion of Indochina. The differential exhumation resulting from thrusting

112 along thrust belts are responsible for relief generation during the Oligocene to Early Miocene

113 (see details in discussion). N-Q: Neogene-Quaternary. The rivers and the faults are marked in

114 their present-day shape and locations. The red line and text indicate the faults were active during 115 this time. 
Table 1. Apatite fission track ages

\begin{tabular}{|c|c|c|c|c|c|c|c|c|c|c|c|c|}
\hline $\begin{array}{c}\text { Sample } \\
\text { No. }\end{array}$ & $\begin{array}{c}\text { Longitude } \\
\left({ }^{\circ} \mathrm{E}\right)\end{array}$ & $\begin{array}{l}\text { Latitude } \\
\left({ }^{\circ} \mathrm{N}\right)\end{array}$ & $\begin{array}{l}\text { Elevation } \\
\text { (m) }\end{array}$ & $\begin{array}{l}\text { Grains } \\
(N)\end{array}$ & $\begin{array}{c}\rho_{\mathrm{s}} \\
\left(10^{6} \mathrm{~cm}^{-2}\right)\end{array}$ & Ns & $\begin{array}{c}\mathrm{U}^{*} \\
(\mathrm{ppm})\end{array}$ & $\begin{array}{l}\mathrm{P}\left(\chi^{2}\right) \\
(\%)\end{array}$ & $\begin{array}{c}\text { Dispersion } \\
(\%)\end{array}$ & $\begin{array}{c}\text { Pooled } \\
\text { Age } \\
(\mathrm{Ma} \pm 1 \sigma) \\
(\%)\end{array}$ & $\begin{array}{c}\mathrm{MTL} \pm 1 \sigma \\
(\mu \mathrm{m}) \\
(N)\end{array}$ & $\begin{array}{l}\text { Dpar } \\
(\mu \mathrm{m})\end{array}$ \\
\hline CD746 & 101.8693 & 28.3298 & 2443 & 24 & 2.595 & 116 & 7.8 & 41.09 & 0 & $26.9 \pm 1.3$ & $\begin{array}{c}13.49 \pm 1.13 \\
(9)\end{array}$ & 1.87 \\
\hline CD747 & 101.8723 & 28.3273 & 2351 & 25 & 2.283 & 91 & 8.6 & 50.24 & 0 & $21.9 \pm 1.9$ & $\begin{array}{c}13.48 \pm 0.51 \\
\text { (9) }\end{array}$ & 1.75 \\
\hline CD748 & 101.8759 & 28.3273 & 2198 & 24 & 2.878 & 80 & 9.6 & 44.05 & 0 & $18.4 \pm 1.4$ & $\begin{array}{c}13.88 \pm 1.10 \\
\quad(11)\end{array}$ & 1.85 \\
\hline CD749 & 101.8773 & 28.3272 & 2093 & 22 & 2.079 & 75 & 9.5 & 42.59 & 5 & $18.5 \pm 1.5$ & NA & 1.99 \\
\hline CD750 & 101.8781 & 28.3291 & 1980 & 23 & 2.238 & 75 & 9.4 & 38.66 & 0 & $19.7 \pm 1.2$ & $\begin{array}{c}13.62 \pm 0.78 \\
\quad(12)\end{array}$ & NA \\
\hline CD751 & 101.8803 & 28.3293 & 1903 & 5 & 1.314 & 22 & 29.2 & 22.84 & 0 & $17.9 \pm 1.2$ & NA & NA \\
\hline CD752 & 101.8772 & 28.3335 & 1676 & 24 & 2.209 & 112 & 10.1 & 55.95 & 0 & $16.9 \pm 0.9$ & $\begin{array}{c}13.85 \pm 0.81 \\
\text { (7) }\end{array}$ & 1.84 \\
\hline CD753 & 101.8774 & 28.3354 & 1545 & 24 & 2.106 & 115 & 9.6 & 42.94 & 0 & $16.9 \pm 1.4$ & $\begin{array}{c}13.89 \pm 0.53 \\
\text { (7) }\end{array}$ & 2.02 \\
\hline CD754 & 101.8795 & 28.3364 & 1455 & 22 & 1.700 & 79 & 9.1 & 51.38 & 0 & $16.7 \pm 1.4$ & $\begin{array}{c}13.84 \pm 1.07 \\
(14)\end{array}$ & 1.85 \\
\hline
\end{tabular}

2 Note: $N=$ Number of grains dated and Number of track length measured; $\rho s=$ spontaneous fission-track density; $N s=$ total number of

3 spontaneous fission tracks counted; $\mathrm{U}^{*}=$ Mean uranium content of all crystals measured by LA-ICP-MS; $\mathrm{P}\left(\chi^{2}\right)=$ chi-squared probability can 4 represent a single population of ages for $v$ where degrees of freedom $v=\mathrm{N}-1$; MTL $=$ Mean confined track length 
5 Table 2 Apatite (U-Th)/He Result From the Baishagou Vertical Profile

\begin{tabular}{|c|c|c|c|c|c|c|c|c|c|c|c|c|c|c|c|c|}
\hline Sample & $\begin{array}{l}\text { Grain } \\
\text { replicate }\end{array}$ & $\begin{array}{l}\text { Radius } \\
(\mu \mathrm{m})\end{array}$ & $\begin{array}{l}\text { Mass } \\
(\mu \mathrm{g})\end{array}$ & $\begin{array}{c}\mathrm{U} \\
(\mathrm{ppm})\end{array}$ & $\begin{array}{c}\text { Th } \\
\text { (ppm) }\end{array}$ & $\begin{array}{c}\text { Sm } \\
(\mathrm{ppm})\end{array}$ & $\begin{array}{c}\mathrm{eU} \\
(\mathrm{ppm})\end{array}$ & $\begin{array}{c}\mathrm{Th} / \\
\mathrm{U}\end{array}$ & $\begin{array}{c}4 \mathrm{He} \\
(\mathrm{nmol} / \mathrm{g})\end{array}$ & $\begin{array}{c}\text { FT } \\
238 \mathrm{U}\end{array}$ & $\begin{array}{c}\text { FT } \\
235 \mathrm{U}\end{array}$ & $\begin{array}{c}\text { FT } \\
232 \mathrm{Th}\end{array}$ & $\begin{array}{l}\text { Raw Age } \\
\text { (Ma) }\end{array}$ & $\begin{array}{c}\text { Corrected } \\
\text { age } \\
\text { (Ma) } \\
\end{array}$ & $\begin{array}{c}1 \sigma \\
(\mathrm{Ma})\end{array}$ & $\begin{array}{l}\text { Average age } \\
\text { (Ma) }\end{array}$ \\
\hline \multirow[t]{4}{*}{ CD746 } & Ap1 & 57.02 & 3.80 & 12.46 & 46.46 & 171.34 & 23.38 & 3.82 & 1.40 & 0.749 & 0.714 & 0.714 & 10.94 & 14.91 & 0.18 & \multirow{4}{*}{$15.16 \pm 1.28$} \\
\hline & Ap2 & 72.39 & 5.15 & 7.75 & 26.34 & 111.61 & 13.94 & 3.49 & 1.01 & 0.799 & 0.771 & 0.771 & 13.25 & 16.82 & 0.19 & \\
\hline & Ap3 & 61.54 & 3.24 & 6.14 & 21.91 & 85.75 & 11.29 & 3.66 & 0.70 & 0.766 & 0.734 & 0.734 & 11.43 & 15.19 & 0.18 & \\
\hline & Ap4 & 56.27 & 3.03 & 7.55 & 26.96 & 105.46 & 13.88 & 3.67 & 0.76 & 0.746 & 0.711 & 0.711 & 10.03 & 13.72 & 0.18 & \\
\hline \multirow[t]{2}{*}{ CD747 } & Ap2 & 60.51 & 3.14 & 7.52 & 19.06 & 156.40 & 11.99 & 2.60 & 0.81 & 0.762 & 0.730 & 0.730 & 12.29 & 16.34 & 0.18 & \multirow{2}{*}{$15.21 \pm 1.59$} \\
\hline & Ap3 & 59.19 & 2.84 & 7.08 & 36.29 & 137.63 & 15.61 & 5.26 & 0.89 & 0.757 & 0.724 & 0.724 & 10.43 & 14.09 & 0.16 & \\
\hline \multirow[t]{4}{*}{ CD749 } & Ap1 & 58.25 & 3.43 & 7.92 & 40.62 & 138.79 & 17.47 & 5.26 & 0.89 & 0.754 & 0.720 & 0.720 & 9.35 & 12.69 & 0.15 & \multirow{4}{*}{$14.27 \pm 1.33$} \\
\hline & Ap2 & 68.21 & 3.74 & 7.98 & 35.11 & 127.44 & 16.23 & 4.51 & 1.00 & 0.787 & 0.758 & 0.758 & 11.27 & 14.57 & 0.15 & \\
\hline & Ap3 & 65.56 & 5.42 & 7.39 & 40.04 & 148.97 & 16.80 & 5.56 & 0.98 & 0.779 & 0.749 & 0.749 & 10.64 & 13.94 & 0.15 & \\
\hline & Ap4 & 53.82 & 3.05 & 9.23 & 45.71 & 150.26 & 19.97 & 5.08 & 1.24 & 0.735 & 0.699 & 0.699 & 11.38 & 15.88 & 0.17 & \\
\hline \multirow[t]{3}{*}{ CD753 } & Ap1 & 57.51 & 4.86 & 8.71 & 31.11 & 141.63 & 16.02 & 3.66 & 1.74 & 0.751 & 0.717 & 0.717 & 19.88 & 26.98 & 0.28 & \\
\hline & Ap3 & 66.89 & 4.96 & 8.28 & 29.21 & 134.60 & 15.15 & 3.62 & 0.72 & 0.784 & 0.753 & 0.753 & 8.71 & 11.29 & 0.12 & \\
\hline & Ap4 & 56.55 & 5.13 & 8.58 & 29.68 & 133.49 & 15.55 & 3.55 & 1.24 & 0.747 & 0.712 & 0.712 & 14.54 & 19.84 & 0.20 & \\
\hline
\end{tabular}

6 The AHe ages that exceed the corresponding AFT age are seemed outliers and not used for weighted mean age calculation and inverse modeling. 
